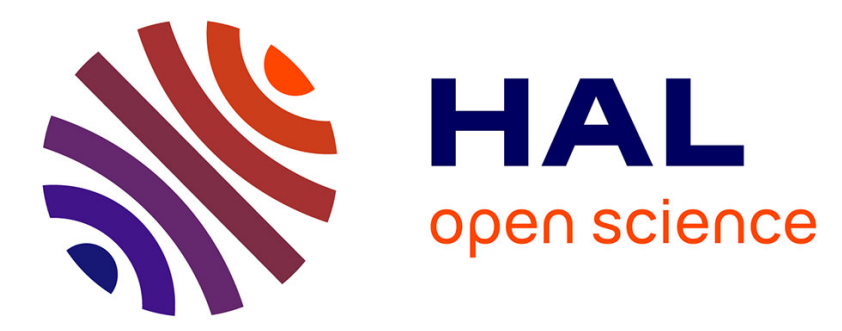

\title{
The indication of Martian gully formation processes by slope-area analysis
}

Susan Conway, Matthew Balme, John Murray, Martin C Towner, Chris H Okubo, Peter M Grindrod

\section{- To cite this version:}

Susan Conway, Matthew Balme, John Murray, Martin C Towner, Chris H Okubo, et al.. The indication of Martian gully formation processes by slope-area analysis. The Geological Society, London, Special Publications, 2011, 356 (1), pp.171-201. 10.1144/SP356.10 . insu-02276823

\section{HAL Id: insu-02276823 \\ https://hal-insu.archives-ouvertes.fr/insu-02276823}

Submitted on 3 Sep 2019

HAL is a multi-disciplinary open access archive for the deposit and dissemination of scientific research documents, whether they are published or not. The documents may come from teaching and research institutions in France or abroad, or from public or private research centers.
L'archive ouverte pluridisciplinaire HAL, est destinée au dépôt et à la diffusion de documents scientifiques de niveau recherche, publiés ou non, émanant des établissements d'enseignement et de recherche français ou étrangers, des laboratoires publics ou privés. 

30 1

The indication of martian gully formation processes by slope-area analysis.

\author{
*Susan J. Conway \\ Work done at: Earth and Environmental Sciences, Open University, Walton Hall, Milton \\ Keynes MK7 6AA UK tel:+44 (0)1908 659777 fax:+44 (0)1908 655151 \\ Now at: Laboratoire de planétologie et géodynamique, CNRS UMR 6112, Université de \\ Nantes, 2 rue de la Houssinière, BP 92208, 44322 Nantes cedex, France tel : +33 (0)251 \\ 125570 Susan.Conway@univ-nantes.fr
}
Matthew R. Balme
Earth and Environmental Sciences, Open University, Walton Hall, Milton Keynes MK7 6AA UK tel:+44 (0)1908 659776 fax:+44 (0)1908 655151 m.r.balme@open.ac.uk
John B. Murray
Earth and Environmental Sciences, Open University, Walton Hall, Milton Keynes MK7 6AA UK tel:+44 (0)1908 659776 fax:+44 (0)1908655151 j.b.murray@open.ac.uk

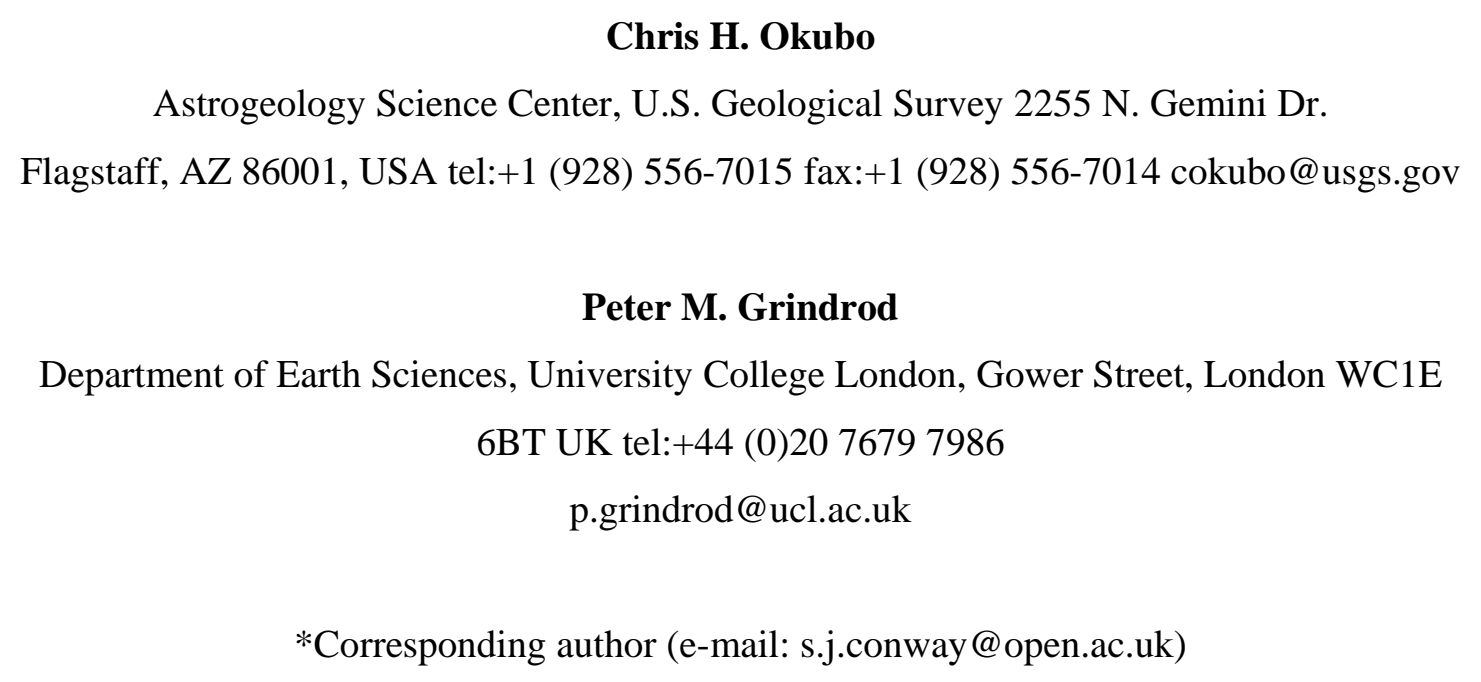

\section{Chris H. Okubo}

Astrogeology Science Center, U.S. Geological Survey 2255 N. Gemini Dr. Flagstaff, AZ 86001, USA tel:+1 (928) 556-7015 fax:+1 (928) 556-7014 cokubo@usgs.gov Peter M. Grindrod Department of Earth Sciences, University College London, Gower Street, London WC1E 6BT UK tel:+44 (0)20 76797986 p.grindrod@ucl.ac.uk *Corresponding author (e-mail: s.j.conway@open.ac.uk) 
34 Number of words: 12624

35 Number of References: 180

36 Number of Tables: 2

37 Number of Figures: 11

38 The styles for each heading level:

$39 \quad$ Heading 1

$40 \quad$ Heading 2

$41 \quad$ Heading 3

42 Running title: Martian gully formation processes.

43 


\section{Abstract}

45 The formation process of recent gullies on Mars is currently under debate. This study aims to

46 discriminate between the proposed formation processes: pure water flow, debris flow and dry

47 mass wasting, through the application of geomorphological indices commonly used in

48 terrestrial geomorphology. We used high resolution digital elevation models of Earth and

49 Mars to evaluate the drainage characteristics of small slope sections. We have used the data

50 from Earth to validate the hillslope, debris flow and alluvial process domains previously

51 found for large fluvial catchments on Earth, and have applied these domains to gullied and

52 ungullied slopes on Mars. In accordance with other studies our results indicate that debris

53 flow is one of the main processes forming the martian gullies that we studied. The source of

54 the water is predominantly distributed surface melting, not an underground aquifer. We also

55 present evidence that other processes may have shaped martian crater slopes, such as ice

56 assisted creep and solifluction, in agreement with proposed recent martian glacial and

57 periglacial climate. Our results suggest that, within impact craters, different processes are

58 acting on differently oriented slopes, but further work is needed to investigate the potential

59 link between these observations and changes in martian climate.

60

61 
62 Martian "gully” landforms were first described by Malin \& Edgett (2000) and defined as

63 features that have an alcove, channel and debris apron with the general appearance of gullies

64 carved by water. Within this definition gullies have a wide range of morphologies (Fig. 1)

65 and they are found in abundance on steep slopes at mid latitudes in both hemispheres on Mars

66 (e.g., Heldmann \& Mellon 2004; Heldmann et al. 2007). They are interpreted to be

67 geologically young features because of the pristine appearance and paucity of superposed

68 impact craters. Recent work has suggested that some gullies have been active in the last

693 - 1.25 Ma (Reiss et al. 2004; Schon et al. 2009). Malin et al. (2006) observed new, high-

70 albedo, dendritic deposits (named light-toned deposits) located along the paths of some

71 gullies, and which formed between subsequent images taken by the Mars Orbiter Camera

72 (MOC). These light-toned deposits have been attributed to either dry mass wasting (Pelletier

73 et al. 2008; Kolb et al. 2010), or debris flow (Heldmann et al. 2010), involving up to $50 \%$

74 water (Iverson 1997). However, the origins of these deposits are still under debate and it is

75 not clear whether they are related to the formation processes of the gullies, or whether they

76 are formed by a secondary process.

77 The formation process for martian gullies in general is also still under debate. Three

78 main candidates exist: (1) aquifer outflow, (2) surface melting, or (3) dry granular flow. In

79 the aquifer model the water is either released from a near surface confined aquifer (Malin \&

80 Edgett 2000; Heldmann et al. 2005) or brought up from depth by cryovolcanic processes

81 (Gaidos 2001). The main criticism of the aquifer based models is their failure to explain the

82 location of some gullies on isolated hills, impact crater central peaks, mesas and sand dunes.

83 Melting of near surface ground ice or surface ice has been proposed for the formation of

84 gullies under recent obliquity excursions (Costard et al. 2002). There is growing support for

85 this model with the most compelling arguments being: (1) the majority of gullies exists at

86 mid-latitudes, (2) the dominance of pole-facing gullies (Balme et al. 2006; Dickson et al. 
87 2007; Kneissl et al. 2009) and, (3) observations of coincidence with sites of seasonal surface

88 ice accumulation (Dickson \& Head 2009). Granular flow has been suggested as either

89 unassisted (Treiman 2003; Shinbrot et al. 2004), or carbon dioxide assisted flow

90 (Musselwhite et al. 2001). The main criticism of the granular flow model is that it fails to

91 replicate some commonly observed features of gullies, in particular channel sinuosity and

92 complex tributary and distributary systems (McEwen et al. 2007).

93 There is also debate about the type of fluid involved: pure water, or brine. Whilst

94 pure water is not stable under the current surface environment on Mars, it can persist in a

95 metastable form (Hecht 2002), although its flow behaviour may be substantially different to

96 water on Earth (Conway et al. 2010a). Brines are a likely product of water sourced from

97 underground and, moreover, the presence of some common geological compounds can

98 substantially depress the freezing point of water (e.g., Chevrier \& Altheide 2008). Brines are

99 less likely in a surface melting scenario, because water ice condensed from the atmosphere

100 will have had less opportunity to dissolve salts than an underground water body. Both pure

101 water and brine can support very high concentrations of entrained sediment, and form a flow

102 commonly termed a "debris flow”. Debris flow is an attractive candidate process for forming

103 gullies, because large amounts of erosion and deposition can be brought about with only 10 to

10450 \% water content (Iverson 1997). Several authors have proposed debris flow as a potential

105 gully-forming mechanism on Mars due to the supply of loose sediment combined with the

106 steep slopes on which gullies are found (e.g., Malin \& Edgett 2000; Balme et al. 2006). The

107 inclusion of debris might also limit evaporation and freezing of the water within the flow.

108 Debris flows on Earth are commonly triggered by sudden and intense or prolonged rainfall,

109 (e.g., Ben David-Novak et al. 2004; Decaulne \& Sæmundsson 2007; Godt \& Coe 2007;

110 Crosta \& Frattini 2008; Morton et al. 2008) which is not a possible mechanism on Mars

111 under recent climate. However, debris flows can also be triggered by snowmelt, or melting 
112 permafrost (Harris \& Gustafson 1993; Decaulne et al. 2005). As noted by Lanza et al. (2010)

113 infiltration rates on Mars are likely to exceed the low discharge rates produced by a surface

114 melting source. Hence, overland flow is unlikely, unless there is a shallow impermeable

115 barrier, such as near-surface permafrost, or frozen layer formed at the base of the water flow

116 on contact with a cold substrate (Conway et al. 2010a). The dominance of infiltration satisfies

117 the conditions for debris flow triggering, sediment saturation and elevated pore pressures.

118 The lack of vegetation and the associated lower cohesion of the martian soil, compared to

119 Earth, potentially means that debris flows can be triggered on much lower slope gradients 120 than they are on Earth.

121 Gullies formed by dilute-water flow and debris flow on Earth can be visually very 122 similar to each other, and the basic structure of gullies can be formed by dry granular flow 123 (Mangeney et al. 2007). In many geomorphological problems, convergence of visual form 124 means that using images alone can make it very difficult to determine process. The ongoing 125 debate regarding the formation mechanisms of gullies on Mars is a prime example of this. For 126 example some workers have dismissed debris flow as a mechanism for forming martian 127 gullies, because they have not observed the levées that are one of the diagnostic features of 128 debris flow (e.g., Innes 1983). However, the ability to identify levées depends on viewing 129 geometry and sun angle; metre sized levées are often not visible on $25 \mathrm{~cm} /$ pixel air photos of 130 Earth. It is also possible that a combination of the lower gravity and different sediment type 131 on Mars means that the levées might be small compared to those on Earth.

132 The amount of water required to carve channels and transport and deposit sediment 133 differs substantially between debris flow, water or brine flow (termed "alluvial” throughout 134 the rest of this paper) and granular flow. Determining the amount of water available at the 135 martian surface is important for questions of martian climate, hydrology and the study of 136 potential martian habitats. Hence, an accurate determination of active processes is needed that 
137 in turn can constrain the quantity of fluid required to form gullies. Quantitative

138 geomorphological study can provide the tools to discriminate between these three processes.

139 The recent availability of high resolution digital elevation models (DEMs) of Mars has

140 opened up the possibility of using quantitative geomorphic methods that have, until now,

141 been restricted to analysing landscapes on Earth. By taking well-developed slope-area

142 analyses and other geomorphic process indicators for the Earth and applying them to Mars,

143 this study aims to give insights into both the processes that formed the gullies on Mars and

144 the source of any water involved.

145 We used three geomorphic tools commonly applied in terrestrial geomorphology to

146 identify active processes forming gullies on Mars: slope-area plots (Fig. 2a), Cumulative

147 Area Distribution (CAD) plots (Fig. 2b) and wetness index maps. These analytical techniques

148 are described in more detail in the following sections. They are usually used to assess active

149 processes within catchment areas and other larger-scale landscape analyses. To test whether

150 they are equally applicable to smaller areas, we first applied them to five study sites on Earth

151 at an equivalent scale to gullies on Mars. Recently deglaciated areas were preferred as these

152 have: (1) a geologically short and well defined slope development history (i.e. since

153 deglaciation) and, (2) a glacial trough valley slope-profile which strongly resembles that of

154 fresh impact craters (compare relationships in Brook et al. (2008) and Garvin et al. (1999).

155 However, suitable quality data could not be found for the alluvial end-member process in

156 glacial environments, so two desert study sites were also included.

157 When we were satisfied that different geomorphic processes could be discriminated

158 on Earth using slope-area plots, CAD plots and wetness index maps, we applied these

159 analyses to slopes containing gullies on Mars. 


\section{Slope-area and Cumulative Area Distribution (CAD) methods}

162 The so-called "stream power law" was first proposed by Hack (1957) and has been widely

163 used to investigate landscape evolution on Earth (e.g., Kirkby et al. 2003; Stock \& Dietrich

164 2003). It is based on the detachment and transport limited rate of bedrock erosion, otherwise

165 known as the shear-stress incision model, which is stated as follows:

$$
S=k A^{-\theta}
$$

167 where $S$ is local slope, $A$ is upslope drainage area, $k$ is a process related constant, which is

168 different for detachment and transport cases, and $\theta$ is the concavity index, which is process

169 dependent. It has also been noted that if the drainage area is plotted against the local slope for

170 drainage basins then process domains can be defined in log-log plots as shown in Fig. 2a

171 (after Montgomery \& Foufoula-Georgiou 1993). These process domains were initially

172 schematic, based on few data, but have been supported by later work (e.g., Whipple \& Tucker

173 1999; Snyder et al. 2000; Kobor \& Roering 2004; Marchi et al. 2008). Brardinoni \& Hassan

174 (2006) added an additional domain in which systems dominated by debris flow deposition,

175 occupy that part of the alluvial domain of Montgomery \& Foufoula-Georgiou (1993), which

176 is located towards higher drainage areas and steeper slopes (Fig. 2a). This domain was

177 proposed from field observations in glacially modified area and has since been supported by

178 additional observations by Mao et al. (2009) in a different geomorphic setting. Process

179 information can be obtained both from the position of the data points relative to defined

180 domains on this slope-area plot, and from the trend of the data within these domains, for

181 example, whether the data points plot in a concave, convex, upward trending, or downward

182 trending curve (Tucker \& Bras 1998). The general trend for an alluvial system is shown in

183 Fig. 2a, which passes through several process domains. The data for such plots are generally 
184 derived from digital elevation models or topographic maps. The slope and contributing area

185 data are either extracted from the channel only, or the whole drainage basin, depending on the

186 focus of the study. In Fig. 2a these data are taken from every pixel contained within the

187 catchment of the whole fluvial system (encompassing valley hillslopes, tributaries, main

188 channels and estuary system) sampled at a single point in time.

189 Cumulative Area Distribution (CAD) is the probability distribution of points in the 190 landscape having a drainage area greater than any particular area, $A^{*}$. The log-log plot of $191 P\left(A>A^{*}\right)$ against $A^{*}$ gives information on the processes acting within a catchment (Perera \& 192 Willgoose 1998; McNamara et al. 2006). Interpretation of this index varies, but generally it is 193 split into three areas: (1) at small drainage areas the plot usually evolves from convex to 194 concave, and represents diffusive erosion, (2) intermediate drainage areas are linear in a log$195 \log$ plot and this is thought to represent incision, (i.e. channel formation), and (3) at large 196 drainage areas there are small steps where major tributaries join the channel (Fig. 2b). 197 McNamara et al. (2006) split domain (1) into three sub-domains (Fig.2b): (1a) a convex 198 section, representing hillslopes that diverge and do not gather drainage, (1b) linear and steep section in a log-log plot, indicating hillslopes with convergent topography and, (1c) a

200 concave section, which they suggest is a reach dominated by pore pressure triggered 201 landsliding (including debris flows which are triggered by this mechanism).

202 The stream-power law (Eq. 1), and process interpretations in slope-area and CAD 203 plots of Montgomery \& Foufoula-Georgiou (1993), Brardinoni \& Hassan (2006) and Tucker 204 \& Bras (1998) are based on empirical hydraulic geometry functions that are predicated on, 205 and developed for, studies of large fluvial systems with channel morphology well-adjusted to 206 perennial discharge. It could therefore be argued that these systems are unlike the hillslope 207 systems in this study. Hence, we have tested these interpretive analysis techniques on small 208 gully-systems on Earth where we know the active processes in order to demonstrate that they 
209 can still be valid. It is, of course, necessary to bear in mind that there is always some

210 uncertainty in inferring process from landscape form, in part due to the intrinsic variability

211 and complexity of natural systems but also due to the effects of vegetation, tectonics, climate

212 and perhaps human interaction with the landscape. However, on Mars the surface processes

213 are likely to be simpler, with little chance of factors, such as rain, vegetation or human action

214 confounding the process domains, so these indices should provide an important addition to

215 the "visual” morphology when inferring process from form.

\section{Application of slope-area method to Mars}

217 The reduced gravitational acceleration of Mars shifts the slope-area boundary of the alluvial

218 slope-area domain vertically (dotted line in Fig. 2a). This means that the unchanneled domain

219 extends to higher slopes for a given drainage area for Mars (extending into the alluvial and

220 debris flow domains for Earth); however the hillslope domain is unaffected. Considering the

221 fact that gullies on Mars do not have large tributary-channel networks it seems unlikely that

222 this domain would be well developed. Appendix 1 gives details of the calculations performed

223 to account for the gravitational acceleration of Mars. The relative gradients and curvatures of

224 the trends described by the alluvial data in slope-area plots are unaffected by the reduced

225 gravity. We have not been able to revise the position of the domain added by Brardinoni \&

226 Hassan (2006) as a function of gravitational acceleration because this domain was added

227 empirically, based on field observations.

228 The slope threshold for dry mass wasting or landsliding in loose material is the same

229 as on Earth (Moore \& Jakosky 1989; Peters et al. 2008). The slope thresholds for pore

230 pressure failure are also unaffected by the difference in gravitational acceleration. Hence

231 there would be no change to these process domains or trends for either dry mass wasting or

232 pore pressure triggered processes such as debris flow. 
We note that on Earth, vegetation cover, soil type and geology can have profound

234 impacts on the slope values in a landscape for a given drainage area (Yetemen et al. 2010),

235 but we would expect only variations in soil type and geology to affect the data on Mars.

236 Despite these differences in surface properties, basins with similar processes on Earth show a

237 similar pattern or trend of data, but displaced vertically in slope-area plots (Yetemen et al.

238 2010).

239 Datasets and generation of digital elevation models

240 Slope-area analysis is only possible with high quality elevation data, preferably at a 241 resolution better than $10 \mathrm{~m}$ per pixel, or 1:25 000 map scale (Montgomery \& Foufoula-

242 Georgiou 1993; Tarolli \& Fontana 2009). For each of the terrestrial sites $1 \mathrm{~m}$ resolution

243 DEMs were derived from airborne laser altimeter (LiDAR) data. These were then

244 resampled to $5 \mathrm{~m}$ resolution to match the Mars data, as described below. Table 1 lists the

245 data sources for the study sites on Earth. The DEM for NW Iceland was produced from the

246 raw LiDAR point data collected by the UK's Natural Environment Research Council's

247 Airborne Research and Survey Facility in 2007 using techniques described by Conway et

248 al. (2010b) and correcting for between-track shifts using methods developed by Akca 249 (2007a, b).

250 For Mars we used four $1 \mathrm{~m}$ resolution DEMs produced using stereo photogrammetry

251 from 25 cm per pixel High Resolution Science Imaging Experiment (HiRISE) images. The

252 DEMs for sites PC, GC, KC and TS were produced by the authors from publically released 253 HiRISE images using methods described by Kirk et al. (2008). Significant metre-scale 254 random noise present in the DEMs of sites GC, KC and TS had a detrimental effect on 255 preliminary slope-area analyses. Hence, all the DEMs were resampled to $5 \mathrm{~m}$ per pixel before 256 the reanalysis was performed. 
258 viewing geometry and pixel scale. For the DEM of site PC, the attendant image pair PSP_004060_1440 (0.255 m/pixel) and PSP_005550_1440 (0.266 m/pixel) have a $12.6^{\circ}$

$0.266 \mathrm{~m} /$ pixel from the more oblique image, the vertical precision is estimated to be $\sim 0.24 \mathrm{~m}$ (cf. Kirk et al. 2008). DEMs for sites GC, KC and TS have a similar magnitude of vertical precision. The pixel matching error is influenced by signal-to-noise ratio, scene contrast and differences in illumination between images. Pattern noise can also be introduced by the automatic terrain extraction algorithm, especially in areas of low correlation. Manual editing is necessary to correct spurious topography in areas of poor correlation (e.g., smooth, low contrast slopes and along shadows). study sites in general reflected the process, or instead were a result of the geometry imposed by the impact crater setting (all the Mars study areas were on the inner walls of bowl shaped depressions, but none of the ones on Earth were). A $10 \mathrm{~km}$ diameter synthetic crater was created by applying a smooth parabolic radial profile, which was derived by fitting curves through ungullied radial profiles of the craters in sites PC and GC. Metre-scale "pink" (also called “1/f”) noise was added to simulate a natural rough surface (Jack 2000).

\section{Derivation of drainage area and local slope}

276 Representative slope sections were chosen in each DEM (Figs. 3 and 4). For Earth, these were chosen to represent end member and intermediate process domains, including dry mass wasting, debris flow and alluvial processes. On Mars, some areas were chosen that covered the complete slope on which gullies are found, whilst others covered a single gully system, or ungullied slope for comparison. Slope sections always included the drainage divide at the top and extended downslope as far as the visible signs of the distal extent of the gully (or slope) 
deposits. Where possible lines delineating drainage basins were followed to define the lateral extent of slope sections, but on poorly incised hillslopes this was not always possible and the lateral extent was defined as a straight line. For site KC, on Mars, we chose different configurations of slope sections to test the sensitivity of our analyses to the exact method used to delineate the slope-sections. Careful delineation of slope sections is necessary for two reasons. Firstly, because the larger the sample area, the more processes are included within it, and the more difficult the results will be to interpret. Secondly, if parts of the slope that are integral to the process to be identified are omitted, then the process signal will not be complete.

The slope and the flow directions of each pixel in each DEM were determined using a "Dinf" algorithm. This algorithm gives flow directions in any direction, rather than only towards one of the eight neighbouring pixels (Tarboton et al. 1991). This has been shown to 294 produce better results from slope-area analysis because it gives a more accurate 295 approximation of the real path of flow through the landscape (Borga et al. 2004). For each pixel, the accumulation of flow was calculated from the flow directions by summing the number of pixels located upstream, and multiplying by the pixel area. These analyses were performed using the TauDEM extension for ArcGIS, based on the algorithms developed by Tarboton (1997). For each DEM the “wetness index” was also calculated. This is the natural logarithm of the ratio of contributing area to slope. It provides information on the potential connectivity of the landscape drainage and the potential ability of the surrounding landscape to route drainage (Woods \& Sivapalan 1997). However, in the case of Earth and particularly in the case of Mars this index should not be interpreted literally as implying that the terrain is "wet”. In our study it is used as a visual aid to interpret the spatial variability of the slopearea plot. For example, highly permeable talus slopes on Earth are essentially dry, but they may have moderate to high wetness index. However, we would expect a talus slope on Earth 
to show a characteristic spatial pattern of wetness index, indicative of dry mass wasting processes. All the DEMs underwent the same processing steps.

311 wide logarithmic bins of drainage area, and then constructed the slope-area and CAD plots.

312 Binning data in this way make the trends in slope-area and CAD plots clearer and is a

313 commonly used display technique (e.g., Snyder et al. 2000).

314 In addition, for one site on Mars (site KC), we visually identified the initiation sites

315 of the gullies on orthorectified HiRISE images. The initiation points for the gullies were

316 defined as the furthest upstream extent defined by a distinct cut, or scarp (Fig. 5a). For each

317 of these locations we extracted the slope and drainage area for the underlying pixel. This

318 analysis was not performed for site PC because edge contamination and noise made it

319 impractical. The analysis was also omitted for site GC because the gullies start at the top of

320 the slope, so would by definition occur at the lowest drainage areas.

\section{Study areas}

\section{Earth}

323 All the study sites on Earth are located in the northern hemisphere and most are within the

324 continental USA. Table 1 provides a summary of the sites and Fig. 3 shows the setting of the 325 areas studied.

\section{Site SJ - San Jacinto, California}

327 This site is located in California along a splay of the San Andreas fault, called the San Jacinto

328 fault. This area is a desert with little rainfall ( $150 \mathrm{~mm}$, annual average recorded by NOAA

329 weather station in nearby Borrego Springs), which has undergone rapid recent uplift caused 
330 by the fault system. The landscape has a well developed ephemeral gully network with large

331 alluvial fans. From the study of the $1 \mathrm{~m} \mathrm{LiDAR}$ data and aerial images we infer the processes

332 forming these fans to be sheet-flow rather than debris flow, based on the lack of levées and

333 lobate terminal deposits. The vegetation is sparse, consisting of small scrub bushes. The

334 underlying geology of the study area is mainly granite, schist and gneiss with minor outcrops

335 of Quaternary older fan deposits (Moyle 1982). For our analyses we used three study areas

336 that contained small complete gully systems, including sources, channels and debris aprons,

337 but avoided large fan systems and debris aprons from neighbouring systems (Figs. 3a and 3b:

338 study areas SJ1, SJ2 and SJ3). Due to the small size of the fans in area SJ1 it is difficult to

339 entirely rule out debris flow as a potential process in forming these alluvial fans.

\section{Site DV - Death Valley, California}

341 This site is located a few kilometres NE of Ubehebe volcano, in Death Valley, California.

342 This is a desert area that has well developed ephemeral gully networks with large alluvial

343 fans. There is little precipitation in this area although the nearby mountains receive as much

344 as $85 \mathrm{~mm}$ of rain per year (Crippen 1979) and rare large storms can do much geomorphic

345 work. Debris flows are found on the fans in the area (e.g., Blair 1999, 2000), but the primary

346 process active in the gullies is alluvial transport (Crippen 1979). We inspected the $1 \mathrm{~m}$

347 LiDAR data for presence of levées and depositional lobes on the fans and found no evidence

348 of these. However, without direct field observations the fact that debris flows do not act on

349 these fans remain an assumption. The bedrock consists of Palaeozoic sedimentary rocks

350 (Workman et al. 2002). We chose two study areas (Fig. 3c: study areas DV1 and DV2) with

351 gully systems that were not affected by neighbouring alluvial fans or gully systems so only

352 receive local rainfall levels. 
354 This site is located east of the abandoned town of Katalla close to the recently deglaciated

355 mountain range of St Elias, near the coast of Alaska and on the border with Yukon, Canada.

356 The area has been unglaciated for approximately the last 10000 years (Sirkin \& Tuthill 1987)

357 and receives very high precipitation, which falls as snow on the upper slopes and rain on the

358 lower. Our study area overlies Tertiary volcanic materials. The slope scarp was generated by

359 the active Ragged Mountain Fault (Miller 1961). The area was neither snow covered nor tree

360 covered at the time of survey and the slopes are composed of steep bedrock cliffs that lead

361 directly into large talus aprons. Debris flow tracks are apparent across this talus slope,

362 especially in study areas KA3 and KA4, and might have occurred in study area KA3 as well

363 (Fig. 3d). Study area KA1 has no evidence of debris flow processes (Fig. 3d).

\section{Site FR - Front Range, Colorado}

365 This site is located in the mountainous eastern side of the continental divide. The area was 366 deglaciated around 14000 to 12000 years before present (Godt \& Coe 2007) and the 367 landscape is dominated by glacially carved valleys. This area has experienced recent debris 368 flows (Coe et al. 2002; Godt \& Coe 2007) and has no permanent snowpack. Our study 369 slopes, located above the tree line, are dominated by Precambrian biotitic gneiss and quartz 370 monzonite, scattered Tertiary intrusions, and by various surface deposits, all of which host 371 debris flows (Godt \& Coe 2007). The head and sidewalls of the cirques have large rockfall 372 talus deposits and which have also experienced recent debris flows. These slopes have little 373 or no vegetation. Three of our study areas (Figs. 3e and 3f: study areas FR2 to FR4) include 374 debris flows located on talus. By way of contrast, we also examined a partially vegetated 375 slope (study area FR1) that is unchanneled and which we infer to be dominated by creep 376 processes (Fig. 3e). 
378 The site is located in NW Iceland and is dominated by fjords and glacially carved valleys.

379 The last glacial retreat occurred approximately 10000 years before present (Norðdalh 1990).

380 The valley walls have many active debris flows (Conway et al. 2010b) and on the slopes

381 above Ísafjörður (Fig. 3g: study area WF1) they occur in most years (Decaulne et al. 2005).

382 The site has a maritime climate, so has high levels of both snow and rainfall, but does not

383 have permanent ice or snow patches. The site is underlain by Miocene basalts, although the

384 debris flows occur most often in glacial till. From this site we chose a study area above the

385 town of Ísafjörður that has very active debris flows (Fig. 3g: study area WF1), two study

386 areas with less active debris flows and more alluvial processes (Figs. $3 g$ and 3h: study areas

387 WF2 and WF3), and one study area dominated by rockfall and rock slide processes, although

388 there are some debris flow tracks visible in the field (Fig. 3h: study area WF4). All these

389 study areas have patchy vegetation, but no trees.

\section{Mars}

391 All the gullies that we studied on Mars were located on the inner walls of craters in the

392 southern hemisphere (Table 2). Slopes both with and without gullies were analysed for 393 comparison. Sites PC, GC and KC were analysed by Lanza et al. (2010), because all the sites 394 showed visual evidence of debris flows.

\section{Site PC - Penticton Crater in Eastern Hellas}

396 This site contains the very recent, light-toned deposits observed by Malin et al. (2006) and 397 interpreted by them to be a recent "gully forming” event. These flows were later suggested by 398 Pelletier et al. (2008) to be produced by dry granular flow, or possibly also debris flow. This 399 slope does not have any well defined channels. We used two study areas within the $\sim 7.5 \mathrm{~km}$ 400 diameter crater for our slope-area analyses, shown in Figs. 4a and 4b. Study area PC1 is 
401 located over the equator-facing light-toned deposits (Fig. 4a) and study area PC2 on the west-

402 facing crater wall which contains small gullies (Fig. 4b). These gullies appear to be incised

403 into “mantle deposits” (Mustard et al. 2001). The mantle is hypothesised to be the remnants

404 of a previously extensive volatile rich deposit (e.g., Mangold 2005). This crater is very

405 asymmetric, with the east and north rims being subdued in terms of elevation (the rim is

406 nearly absent on the east side) whilst the southern rim is abrupt and steep.

\section{Site GC - Gasa Crater in Terra Cimmeria}

408 This $\sim 7 \mathrm{~km}$ wide crater, shown in Figs. 4c and 4d, has well developed alcoves or 409 indentations into the rim of the crater. Gully channels are most obvious on the west-facing to 410 pole-facing slopes (Figs. 4c and 4d) and the equator-facing slope lacks these well defined 411 alcoves and channels (Fig. 4e). We chose sections on the pole- (study areas GC1 and GC2), 412 west- (study area GC3) and equator-facing (study area GC4) slopes. This crater is located 413 within a larger crater, which also has gullies on its west- to pole-facing slopes. There is no 414 evidence of mantle deposits being present anywhere within this crater.

\section{Site $K C$ - crater inside Kaiser Crater in Noachis Terra}

416 The study crater, $\sim 12 \mathrm{~km}$ across is located within the larger Kaiser crater, which not only has 417 gullies down its own rim, but also gullies on the dunes within it (Bourke 2005). Gullies in 418 this crater have alcoves at various positions on the slope, which converge to form well 419 defined tributary networks. Lateral levées bound some of the channels (Figs. 5b and 5c). This 420 slope has the subdued appearance often attributed to the presence of volatile rich mantle 421 deposits (Mustard et al. 2001). We chose study areas that encompass the drainage area of two 422 gullies (study area KC2), a single gully (study area KC1) and also the slope section as a 423 whole (study area KC3), all of which are shown in Fig. 4f. We chose study area KC4, an area 424 of the slope not affected by gullies, for comparison (Fig. 4f). 
426 This $\sim 7 \mathrm{~km}$ diameter crater is located to the south of Pickering Crater in Terra Sirenum and 427 contains pole-facing gullies. We analysed an equator-facing slope (Fig. 4g: study area TS1)

428 which has no evidence of channels but contains an apparently well developed talus apron.

429 There is no evidence of mantle deposits being present on this slope.

\section{Results}

\section{Earth}

432 Initially we chose two study areas with talus and with active creep. The slope-area analysis 433 results for these are shown in Fig. 6a. The study areas with well developed talus (WF4 and 434 KA1) show the following pattern on log-log plots: (1) At small drainage area the curves are 435 initially flat. (2) There is then a linear decrease in slope with increasing drainage area. (3) The 436 curve then becomes horizontal again at higher drainage area with a lower slope value. Talus 437 slopes that have a mixture of processes (e.g., KA2) show a curve that drops off linearly in 438 log-log plots then flattens at higher drainage areas.

439 The CAD plot (Fig. 7a) provides additional information: the talus dominated study 440 areas have a very smooth convex shape. The gradient of the curve is low until the drainage 441 area is between approximately $0.001 \mathrm{~km}^{2}$ after which the curve drops sharply and continues to steepen with increasing drainage area.

443 The soil creep diffusive process study area (FR1 in Fig. 6a) shows a distinctive 444 signature in slope-area plots: (1) The curve is initially horizontal to gently downwards 445 sloping. (2) Between drainage areas of 0.0001 to $0.001 \mathrm{~km}^{2}$ the slope increases linearly with 446 increasing drainage area. (3) There is then a marked slope turnover at which the curve 447 switches to decreasing slope with increasing drainage area. The soil creep diffusive process 448 study area resembles the talus slopes in CAD plots (FR1, Fig. 7a). 
Figs. $6 \mathrm{~b}$ and $7 \mathrm{~b}$ show the debris flow study areas that are influenced by talus processes and Figs. 6c and 7c show those that are more influenced by alluvial processes.

451 Generally in slope-area plots debris flow produces a curve that drops off linearly in log-log 452 plots, flattening off before finally dropping away steeply. The difference between the talus 453 study areas (e.g. KA2, Fig. 6a) and the debris flow study areas influenced by talus (Fig. 6b) is

454 subtle in some cases. In a similar way the difference between the debris flow areas influenced 455 by talus processes (Fig. 6b) and those influenced by alluvial processes (Fig. 6c) is also subtle. 456 Without field information it would be difficult to differentiate talus dominated and debris 457 flow dominated slopes reliably in slope-area plots (e.g., compare Figs. 6a, KA2 and 6b). 458 However, in CAD plots it is possible to differentiate between the two process types. The 459 debris flow dominated study areas (Figs. 7b and 7c) show the following pattern: (1) The 460 curve drops away from the horizontal slowly (but faster than the talus slopes) at small

461 drainage areas. (2) The curve then either dips down linearly, or follows a flattened convex 462 path, and (3) at high drainage areas the curve drops away sharply with increasing drainage 463 area.

Study areas modified by ephemeral water flow have distinct signatures in slope-area 465 plots (Fig. 6d) and in CAD plots (Fig. 7d). In slope-area plots they show a shallow linearly 466 decreasing trend at small drainage areas, which gets steeper at higher drainage areas, and 467 drops into the alluvial domain. The CAD plot drops away from the horizontal slowly and then 468 dips down linearly (or even with a concave profile) until the tail of the curve drops sharply 469 off at the highest drainage areas.

\section{Synthetic Crater}

471 The slope-area and CAD plots for the synthetic crater are easily differentiated from the 472 process study areas that we have examined on Earth. In slope-area plots the synthetic crater 473 produces a hump-backed curve (Fig. 8d): at small drainage areas the curve rises steeply, then 
474 levels off and drops at high drainage areas. In appearance the curve is, as expected, nearest to

475 study area FR1, the area dominated by diffusive creep (Fig. 6a). In CAD plots (Fig. 9d) the 476 line follows a smooth convex arc, similar to that shown by talus on Earth, except without a 477 break in gradient.

\section{Mars}

479 The slope-area plots for sites PC and GC (Penticton Crater and Gasa Crater inner slopes) 480 closely resemble each one another (Fig. 8a and b). The resulting curve can be divided into 481 three zones: (1) A short initial increase in slope with increasing drainage area, followed by a 482 slope turnover at very small drainage areas. (2) A linear or slightly concave decreasing slope 483 trend with increasing drainage area that continues for most of the plot. (3) Finally, at the 484 largest drainage areas, there is a steep decrease in slope with increasing drainage area. For 485 study area PC1 there is a distinct and linear decline in slope with drainage area, whereas for 486 study areas PC2, GC1, GC2 and GC3 this section is slightly concave. The drop-off at the 487 highest drainage areas occurs at lower absolute drainage area values than for site GC. In the 488 CAD plot, study areas PC1 and GC4 have a smooth convex form, whereas study areas PC2, 489 GC1 and GC2 all have a nearly linear, flattened section at intermediate drainage areas (Figs. 490 9a and 9b). Study area GC3 lies close to PC1, GC1 and GC2 but without any sign of 491 flattening.

492 The slope-area plots for gullies in study areas KC1, KC2 and KC3 (Fig. 8c) can be 493 split into three sections as follows: (1) at small drainage areas the curve is sub-horizontal with 494 a subtle upward trend. This trend is more apparent for the data from individual gullies than 495 the data obtained from the whole slope section and is somewhat variable between gully 496 systems. (2) At intermediate drainage areas there is a transitional zone, occurring at different 497 drainage areas for each gully system, in which slope drops off markedly with drainage area. 
498 (3) At higher drainage areas there is a gently declining relationship between slope and drainage area, which is the same for all the gully systems.

500 The ungullied study area (KC4) is also shown in Fig. 8c. This study area has a

501 hump-back shape, resembling that seen for the synthetic crater. The hump occurs across the 502 same slope values as the transition zone (2) for the gullied slopes. In CAD plots (Fig. 9c) 503 study areas KC2 and KC3 have a flattened section at intermediate drainage areas, followed 504 by a steepening decrease at higher drainage areas. The study area without gullies (KC4) has a curve that is convex and initially declines slowly, before dropping off steeply. Study area

506 KC1 has a less flattened profile than study areas KC2, or KC3 and it seems to be a mixture 507 between slope types typified by gullied study areas KC2 or KC3 and ungullied study area 508 KC4.

509 In slope-area plots, study area TS1, an ungullied slope, shows a slope-area turnover 510 at small drainage areas, followed by a decreasing and slightly concave trend in slope with 511 drainage area (Fig. 8d). There is a slight upturn at the highest drainage areas, but this is likely

512 to be an artefact caused by few data-points being used to calculate the mean slope in these 513 bins. In CAD plots (Fig. 9d) study area TS1 has a very smooth convex curve.

514 The slope and drainage area of the gully head initiation points were recorded for site

515 KC. These data are displayed on Fig. 8c. Interestingly, the locations of the gully heads cluster 516 around the range of drainage areas of the transitional section in the slope-area plot, but are 517 located at higher slope values.

\section{Wetness Index on Earth and Mars}

519 The spatial distribution of the slope-area data is most easily visualised using a wetness index 520 map. Maps of wetness index are presented for Earth (Fig. 10) and for Mars (Fig. 11). The

521 alluvial study areas in Earth sites SJ and DV show very low overall wetness indices - only 522 the channels have significant wetness index (Figs. 10a, 10b, and 10c). Debris flow study 
523 areas are slightly more complex (Figs. 10d, 10e, 9f, 10g, and 10h): the slopes generally have

524 moderate wetness index, but there are localised paths along which the wetness index is

525 higher. Site WF (Figs. 10g and 10h) is the best example of this pattern, but it is also the area

526 with the highest influence of overland flow. For site KA (Fig. 10d) this signature is poorly

527 developed, but this site has been influenced by talus processes. The creep dominated study

528 area, FR1, has moderate wetness index throughout (Fig. 10e). The talus study areas KA1,

529 KA2 (Fig. 10d) and WF4 (Fig. 10h) show lobe-like areas of low wetness index with widening

530 streaks of higher wetness index in between.

531 On Mars, study area PC1 (Fig. 11a) and the synthetic crater (Fig. 11h) have similar

532 wetness index maps: the slope generally increases in wetness index going downhill and there

533 are quasi-linear streaks of higher wetness index that increase in value going downslope.

534 Study area PC2 (Fig. 11b) has overall low wetness index, apart from concentrated lines of

535 high wetness index within the gully alcoves, that spread and become more diffuse in the

536 debris aprons. A similar overall pattern is shown for study areas GC1, GC2 and GC3 (Figs.

537 11c and 11d), but the ridges around the alcoves have very low wetness index. Study area GC2

538 in particular (Fig. 11c) shows very concentrated slightly sinuous high wetness index lines on

539 its debris apron. However this part of the DEM contains significant noise, making it hard to

540 judge whether this is simply an artefact. Study areas GC4 (Fig. 11e) and TS1 (Fig. 11g) have

541 similar wetness index maps: there is low wetness index at the crest of the slope and where

542 bedrock is exposed and the wetness index generally increases downslope, but this trend is

543 superposed with diffuse linear streaks of higher relative wetness index. Site KC (Fig. 11f) has

544 generally moderate wetness index, with the alcoves and channels of the gullies showing

545 focussed high wetness index flanked by much lower wetness index and the debris aprons

546 having generally high wetness index with diffuse downslope streaking. 


\section{Discussion}

548 Comparison of Earth data to previously published slope-area 549 process domains

550 There are two interlinked methods of determining slope processes from slope-area plots:

551 (1) The data points fall within domains in the plots which have been found both theoretically

552 and empirically to relate to particular processes, and

553 (2) The data points exhibit trends and gradients that provide information on active processes.

554 We compared our data from Earth to the slope-area process domains of Montgomery

555 \& Foufoula-Georgiou (1993) and the additional domain added by Brardinoni \& Hassan

556 (2006), shown as solid lines in Fig. 6. The data from our creep, talus and debris flow analyses

557 fall into the debris flow domain of Montgomery \& Foufoula-Georgiou (1993). However,

558 some of our debris flow data drop into the alluvial domain at the highest drainage areas.

559 Because they are small systems with limited drainage areas, however, only a few points fall

560 within the alluvial domain. Some of our data approach the additional domain added by

561 Brardinoni \& Hassan (2006), but do not extend towards sufficiently high drainage areas (or

562 low drainage areas) to enter it (Fig. 6b and 6c). Our data from the alluvial systems (Fig. 6d)

563 fall into both the debris flow and alluvial domains. They start to trend downwards in slope-

564 area plots at lower drainage areas than our debris flow systems.

565 Tucker \& Bras (1998) simulated the effects of different dominant processes on

566 slope-area plots and we now compare their model results to the patterns in slope-area plots

567 shown by our data. Our talus systems (Fig. 6a) closely fit their model of a landscape

568 dominated by landsliding (which includes the process of debris flow). In slope-area plots our

569 talus data have an initial flat section at small drainage areas, which represents the slope

570 threshold for the rock wall failure and so differs between localities. At higher drainage areas 
571 the curves are again flat, representing the failure threshold of loose talus, which is consistent

572 for all areas at approximately 0.7 gradient, equivalent to a slope of approximately $35^{\circ}$. This is

573 an approximate mean slope angle for talus slopes on Earth (Chandler 1973; Selby 1993) and

574 is shown by a dotted horizontal line in Figs. 6 and 8. Between these two horizontal sections

575 there is a transition where the dominance shifts from rock wall failure to unconsolidated talus

576 failure.

577 Within the framework of Tucker \& Bras (1998) the pattern shown by the debris flow

578 slopes on Earth (Figs. 6b and 6c) is most consistent with the transition from unsaturated

579 landsliding (dry mass wasting of both talus and rock wall) to pore pressure triggered

580 landsliding (which we interpret to also include debris flow), in a landscape dominated by

581 landsliding. The presence of processes with a slope failure threshold cause data in slope-area

582 plots to fall along horizontal lines. Hence, as the process dominance changes from rock wall

583 failure (highest threshold) to unsaturated landsliding (intermediate threshold) to saturated

584 landsliding (lowest threshold) the curve declines and levels off at the slope value of the

585 saturated landslide threshold in that particular area. As each physical locality has its own

586 saturation threshold this horizontal section occurs at different slope values for different

587 localities but is always located below the dry stability line at 0.7.

588 In slope-area plots, our data from alluvial systems on Earth (Fig. 6d) show a simple

589 decline of slope with drainage area, possibly steepening at higher drainage areas. The data are

590 scattered at drainage areas $>0.001 \mathrm{~km}^{2}$, due to the limitations of the small sizes of the gully

591 systems available. This means a relatively small number of pixels were used to generate each

592 point, leading to random scatter. However, even taking into account the scatter, the data are

593 below the slope threshold for dry slope failure at 0.7 gradient, which suggests a gradual

594 transition from pore pressure dominated landsliding to fluvial processes. 
596 from increasing slope with drainage area to decreasing slope with drainage area. One of the

597 alluvial systems in site SJ (study area SJ3) shows a weak slope turnover at the lowest

598 drainage areas but none of the other plots show this feature. The slope-area turnover is shown

599 in Fig. 2 and is generally expected to occur in slope-area plots (e.g., Tucker \& Bras 1998). It

600 usually occurs in, or close to, the "hillslope" domain of Montgomery \& Foufoula-Georgiou

601 (1993). The turnover represents a transition from convex slopes dominated by diffusive

602 processes (which include soil creep often modified by plant roots and other biota) to concave

603 slopes dominated by advective, or alluvial processes. Within the diffusive processes domain

604 in slope-area plots, slope increases with drainage area. The most likely reason that most of

605 our data do not show this turnover is that the slopes we studied lack stable vegetation

606 (Dietrich \& Perron 2006; Marchi et al. 2008). Another potential contributing factor is that the

607 bedrock and colluvium in our study areas are not naturally cohesive, for example, clay-rich

608 rocks can exhibit convex creep-dominated slopes in unvegetated badlands on Earth.

609 The pattern of data in slope-area plots shown by our alluvial systems and some of

610 our debris flow systems (slow decline at small drainage areas followed by a steep decline at

611 higher drainage areas) has been shown from numerous remote sensing and field studies to

612 mark the transition from the colluvial (including debris flow) regime, to that of a fully fluvial

613 regime (e.g., Lague \& Davy 2003; Stock \& Dietrich 2003; Stock \& Dietrich 2006). Some

614 have described the transition as a separate linear portion of the plot between the colluvial and

615 the fluvial (Lague \& Davy 2003) and some as a gradual curved transition (Stock \& Dietrich

616 2003). However, both are consistent with Tucker \& Bras’ (1998) transition from pore

617 pressure triggered landsliding into a fully fluvial system. Our plots do not show a well

618 developed alluvial regime, but this is due to the use of high resolution data of very small

619 areas rather than large, well developed fluvial catchments. 
In summary, our terrestrial data are consistent with published slope-area process

621 domains, and provide reassurance that the method is applicable and that the Mars data can be

622 used to infer process in a similar way. The caveat to this is that the environmental differences

623 between Earth and Mars, as detailed in the introduction, must be considered when comparing

624 terrestrial process domains to data from Mars. Furthermore, improved process discrimination

625 can be made by considering CAD profiles in addition to slope-area analysis.

\section{Comparison of Earth data to published CAD process domains}

627 Comparison of all our CAD plots for Earth (Fig. 7) to the published process domains for

628 CAD (Fig. 2) reveals that our data do not generally follow the cited trends. This is possibly

629 because we are studying small areas, rather than large catchments. However, the shape of the

630 curve outlined by our data in CAD plots does allow process discrimination and does follow

631 some of the framework outlined by McNamara et al. (2006). Specifically region 1 on Fig. 2

632 has three sub-regions whose shapes can be recognised in our datasets. The talus data (Fig. 7a)

633 and synthetic crater (Fig. 9d) are both convex in their CAD plots, resembling most closely

634 region 1a of McNamara et al. (2006). They describe this region as representing "hillslopes

635 that diverge and do not gather drainage.” Our alluvial data and some of our debris flow data

636 show a flattening of the CAD plot curve in the middle region, giving a steep linear section,

637 corresponding to either region 1b or region 2 (Fig. 2b) which McNamara et al. (2006)

638 describe as slopes that are convergent (1b), or channel forming (2). Two debris flows (WF2

639 and WF3 in Fig. 7c) show a concave section, which would correspond to region 1c of

640 McNamara et al. (2006) and which they attribute to pore pressure triggered landsliding or

641 debris flow.

642 The similarity of talus and debris flow in slope-area plots can be attributed to their

643 similarly linear long profiles. However, the two processes produce different patterns in CAD 
644 plots because talus slopes tend to disperse drainage but debris flow slopes tend to have

645 convergent drainage. This can also be seen in the wetness index plots (Fig. 10).

646 This difference of behaviour in CAD and wetness index plots, in addition to the

647 information from the slope-area plots, shows that we can detect slopes dominated by alluvial,

648 debris flow and dry mass wasting on the basis of these parameters, even for small catchments

649 such as individual gullies or debris flow tracks. However, it should be noted here that these

650 analyses have been performed on relatively few sample sites on Earth and some of the

651 differences are subtle. Future work has to include extending this analysis to a greater number

652 of test sites on Earth to verify that this kind of process discrimination is robust. Using these

653 initial results we continue and apply these methods of process discrimination to Mars.

\section{Process domains for gullies on Mars}

655 In slope-area plots all the Mars slope sections, except study area TS1, fall below the slope 656 threshold for dry mass wasting (dotted line in the plots in Fig. 8). This means that talus-like 657 dry mass wasting is not a dominant process in these areas. However, study area TS1, visually 658 similar to talus on Earth, is not only above the slope threshold for dry mass wasting, but also 659 bears a signature similar to talus on Earth in the combination of its slope-area plot, CAD plot 660 and wetness index map

661 Within the process domains of Montgomery \& Foufoula-Georgiou (1993) the 662 majority of the Mars data lie within the debris flow domain, with some data located in the 663 debris flow deposition domain added by Brardinoni \& Hassan (2006) and a few in the 664 alluvial domain. The difference in gravity between Earth and Mars requires an upwards slope 665 adjustment to the alluvial channels domain boundary (see Fig. 2a) in slope-area plots 666 (Appendix 1), but does not change the gradient of the line. This is marked by the dash-dot 667 line on the plots in Fig. 8. This shift places more data in the unchanneled domain, but does 668 not place any additional data into the alluvial or debris flow domains. This in itself 
669 distribution does not provide very detailed information on the formation mechanisms for

670 gullies. However, by combining slope-area trends, CAD plots and wetness index maps we

671 can make more detailed assessments. We examine each of the study areas on Mars in turn

672 and then discuss the overall implications for the gully formation processes.

\section{Synthetic Crater}

674 The pattern in slope-area plots of the interior of impact craters is, in part, a result of 675 the inherent shape of the crater slope which in turn is due to the impact process and the 676 modification that occurs immediately afterwards. The slope of a fresh impact crater is 677 concave and exponentially shaped in profile (Garvin et al. 1999). Thus in slope-area plots it 678 resembles a well developed alluvial system on Earth (e.g., Hack 1957). This reinforces the 679 uncertainty in inferring a unique process from slope form. In CAD plots, however, the 680 synthetic crater data show a similar pattern to that of talus slopes on Earth, indicating that at 681 short length-scales this type of slope cannot channelise flow on its own. This interpretation is 682 supported by the wetness index plot (Fig. 11), which shows a slowly coalescing flow, rather 683 than discrete areas of fluid concentration.

685 In slope-area plots the slope turnover is well expressed for both study areas in site 686 PC (Fig. 8a). This suggests a strong diffusive or creep influence on both slopes. Study areas 687 PC1 and PC2 both resemble either poorly developed talus or debris flow in slope-area plots. 688 In the CAD plot (Fig. 9a); however, study area PC2 has the distinctive profile associated with 689 debris flow, whereas study area PC1 more closely resembles talus. Talus processes can only 690 be active in study area PC1 at small drainage areas, where it lies on the dry mass wasting 691 threshold in slope-area plots. Hence the shape of the CAD curve must be explained by 692 another process, which has a slope threshold but does not concentrate drainage. This 
693 unknown process must be pore pressure triggered as it is below the slope for dry mass

694 wasting. In addition, the wetness index plot reveals that study areas PC1 and PC2 are very

695 different: study area PC1 has a similar wetness index map to the synthetic crater (Fig. 11h),

696 whereas study area PC2 resembles debris flow areas on Earth (e.g., Fig. 10f) with strongly

697 concentrated high wetness index within alcoves and channels, becoming more diffuse down

698 slope on the debris aprons.

699 The combined evidence suggests that the west-facing slope, which contains small

700 gullies, has been modified by debris flow, whereas the equator-facing slope is more similar to

701 dry mass wasting deposits. This agrees with the interpretation of Pelletier et al. (2008), who,

702 using numerical modelling, concluded that the new bright toned deposits on this slope were

703 more similar in form to deposits of dry granular flows than debris flows.

\section{Site GC - Gasa Crater in Terra Cimmeria}

705 In the slope-area plot for site GC (Fig. 8b), the slope-turnover occurs at very small

706 drainage areas (one or two pixels) and is thus partly abbreviated. This suggests that creep has

707 not strongly influenced this site. This interpretation is supported by the observation that the

708 gully heads originate at the very top of the slope. Study areas GC1, GC2 and GC3 resemble

709 either poorly developed talus on Earth (study area KA2, Fig. 6a) or debris flows on Earth

710 (Figs. 6b and 6c) in slope-area plots. However, in CAD plots (Fig. 9b) they have a flattened

711 mid-section, resembling debris flow systems on Earth. Their wetness index plots (Figs. 11c

712 and 11d) have strong similarities with debris flow systems on Earth (e.g., Fig. 10g): showing

713 flow concentration in the alcove and channel with more diffuse flow on the debris apron.

714 Study area GC2 (Fig. 11c) shows a similar pattern of wetness index to the alluvial systems on

715 Earth, with focussed flow throughout.

716 In slope-area plots (Fig. 8b) study area GC4 has a flatter profile than study areas

717 GC1, GC2 and GC3. The drop in slope at high drainage areas in GC4 is probably an artefact 
718 of the low number of pixels included in the slope calculations in the last 5 to 10 points. In the

719 CAD plot (Fig. 9b), study area GC4 has a similar shape to talus systems on Earth (Fig. 7a).

720 The talus interpretation for GC4 is supported by additional evidence: (1) there is no evidence

721 for channels (Fig. 4e), (2) the wetness index plot (Fig. 11e) is similar to talus slopes on Earth

722 and (3) part of the slope-area curve lies on the threshold for dry mass wasting (Fig. 8b). The

723 dip of the slope-area curve away from the threshold for dry mass wasting suggests that

724 another process with a lower slope threshold is acting, either without having an effect on the

725 CAD plot, or with the same CAD plot as talus. We hypothesise that this may be the same 726 unknown process as noted in study area PC1.

727 The combined evidence suggests that the pole and east facing slopes of the crater

728 have been affected by debris flow processes and the equator-facing slope by mass wasting

729 and an unknown process.

\section{Site $\mathrm{KC}$ - crater inside Kaiser Crater in Noachis Terra}

731 Our ungullied study area (KC4) shows patterns in slope-area (Fig. 8c) and CAD plots (Fig.

732 9c) very similar to the synthetic crater and creep slopes on Earth. The difference between this

733 study area and the gullied study areas (KC1 to KC3) is presumably a result of the process of

734 gully formation. Study areas KC1 to KC3 do not have slope-area plots (Fig. 8c) that fit easily

735 within the framework established so far. However, if we refer to the modelling work of

736 Tucker \& Bras (1998) then the patterns in slope-area plots can be explained. At small

737 drainage areas our curves for study areas with gullies have a horizontal or slightly positive

738 trend compared to our ungullied study area, which has a definite positive trend. This suggests

739 the weak influence of diffusive processes (which generate a positive relationship in slope-

740 area plots) combined with slope threshold processes (which tend to produce horizontal

741 trends). As all the data are below the dry mass wasting threshold, this threshold process is

742 likely to be a pore pressure triggered process, such as debris flow. At intermediate drainage 
743 areas there is a transitional region which occurs at a similar drainage area to the slope-

744 turnover in the ungullied section. At high drainage areas the gullied study areas show a

745 slightly decreasing sub-horizontal trend, as opposed to the ungullied study area which has a

746 well defined decrease in slope with drainage area. This also can be attributed to a pore

747 pressure triggered threshold process but at a lower slope threshold than the previous process.

748 In CAD plots (Fig. 9c) study areas KC1 to KC3 are consistent with debris flow processes.

749 The wetness index plots for these study areas (Fig. 11f) are similar to terrestrial debris flow

750 study areas which have been influenced by alluvial processes (e.g., site WF, Figs. 10g and

751 10h). This suggests that the first pore pressure threshold in slope-area plots is due to debris

752 flow and the second lower one due to an unknown process, which again could be the same 753 process affecting sites PC and GC.

754 In slope-area plots, the gully heads on this slope (Fig. 8c) coincide with the drainage 755 area of the slope turnover in study area KC4 and the transitional study areas of KC1 to KC3.

756 This coincident relationship matches the observations made by many authors who have 757 studied gullies on Earth (e.g., Hancock \& Evans 2006). Our channel heads lie mainly in the 758 domain attributed to "pore pressure landsliding channel initiation” processes, but some also 759 lie in the "unchanneled" domain (McNamara et al. 2006). Notably the gully heads occur 760 below the dry mass wasting threshold, again suggesting that these martian gullies are initiated 761 by a pore pressure threshold process. The gully heads occur on slope gradients of 0.55 similar 762 to those described by Lanza et al. (2010), but at drainage areas an order of magnitude lower.

763 This is possibly due to the different approach used by Lanza et al. (2010) to measure the 764 contributing area, and possible differences in their interpretation of the location of channel 765 initiation. The co-occurrence of the gully heads with the slope-turnover in slope-area plots 766 suggests that the gullies are a result of whole-slope drainage, as previously found by Lanza et 767 al. (2010), either at the surface or shallow subsurface. Our work provides additional evidence 
to support the conclusions of Lanza et al. (2010) that these gullies originate from a distributed source and hence supports the surface melting model for martian gully formation, rather than an aquifer source model. Further, this observation provides additional evidence that a threshold process, probably debris flow, is forming these gullies, as previously suggested by Lanza et al. (2010). the gullies in this crater are produced by debris flow and were initiated by surface, or near subsurface, flow of water. Creep and an unknown process were likely to have been the dominant processes on the ungullied crater slopes. This is consistent with the setting of these

777 gullies within the ice-rich mantle deposits which is likely to be susceptible to melting, 778 providing a distributed source of water for the gullies.

Unlike the other areas we have studied on Mars, parts of the slope-area data for study area TS1 at lower drainage areas (Fig. 8d) are above the threshold slope for dry mass wasting. This is an indication that rock strength limited dry mass wasting is occurring in the upper parts of the slope. In CAD plots (Fig. 9d) this study area has the classic shape of a talus or creep slope. However, the slope-area trend shown by study area TS1 is very different from that of the synthetic crater (Fig. 8d), which we assume to have been similar to the starting point for study area TS1. This assumption carries the implication that the slope in study area TS1 has evolved over time from concave to linear in profile. Study area TS1 shows a very similar trend in slope-area plots as study area GC4 (Fig. 8b), but originates above the 0.7 slope threshold. As discussed previously for study area GC4, in the framework of Tucker \& Bras (1998) such a pattern is likely to reflect a gradual transition from the dominance of a dry mass wasting threshold at lower drainage areas to the dominance of a pore pressure triggered slope threshold due to an unknown process at higher drainage areas. However, in the case of 
793 TS1 this signal not only includes dry mass wasting of non-cohesive material, but rockwall

794 mass wasting as well. The wetness index map shows that the slope does not concentrate

795 drainage, except for some diffuse linear areas, again resembling talus slopes on Earth. The

796 combination of the slope-area plot, CAD plot and wetness index map suggests a dominantly

797 dry mass wasting evolution of this slope, which fits well with the visual observations.

798

799

800

801

802

803

804

805

806

807

808

809

810

\section{Implications for the formation process of martian gullies}

812 Dietrich \& Perron (2006) suggested that the lack of biotic processes on Mars would promote

813 erosion by rilling and gullying and stripping of the fine surface materials, given a suitable

814 water source. This would lead to a slope-area plot that lacked a distinct slope turnover,

815 similar to the slope-area plots seen in the Death Valley data (our site DV - Fig. 6d).

816 However, inspecting the trends in the slope-area plots for the Mars systems in Fig. 8, one of 
817 the most apparent differences from Earth is the presence of this slope turnover. This indicates

818 that creep is a more dominant process on martian hillslopes than on those we studied on

819 Earth; contradictory to the predictions made by Dietrich \& Perron (2006). The creep signal

820 in most published slope-area plots on Earth is induced predominantly by biota, hence on

821 Mars the creep must be facilitated using a different mechanism. Perron et al. (2003) observed

822 using Mars Orbiter Laser Altimeter (MOLA) data that slopes on Mars have average gradients

823 well below $35^{\circ}$ and suggested that ice driven creep is the cause. Other potential creep

824 mechanisms include frost heave and shrink-swell in clays and hydrated salts, both of which

825 produce creep on un-vegetated and un-bioturbated slopes on Earth. These mechanisms

826 however would require widespread and relatively large amounts of liquid water, which is

827 considered unlikely under current or geologically recent martian climate. Hence, we believe

828 that ice driven creep provides the best explanation for the signals seen in our slope-area data

829 from Mars. In accordance with their results, most of the slopes we studied on Mars also have

830 average gradients well below $35^{\circ}$, with the exception of slope TS1, whose average gradients 831 are partially above $35^{\circ}$.

832 Virtually every gully that we have studied on Mars has the distinct signal of debris

833 flow as the dominant gully forming process. Lanza et al. (2010) also found visual and

834 morphometric evidence of debris flows in these areas. The notable exception is area PC1, the

835 slope containing the new light-toned deposits. However, this area does not include gullies of

836 a normal form (Fig. 1) as they lack well defined alcoves and channels. Examination of a far

837 greater number of DEMs containing gullies would be needed to confirm debris flow as the

838 main gully forming process on Mars. However, if this is the principal mechanism, brings up

839 the following hypotheses and predictions for the formation of gullies on Mars:

840 (1) The high sediment concentrations and low infiltration rates could protect the water 841 from evaporation. 
842 (2) The energy released by grain interactions within the flow could retard freezing.

843 (3) Basal freezing (Conway et al. 2010a) or a permafrost layer could facilitate the 844 saturation of the sediment that is required to generate the high pore water pressures 845 to trigger debris flow.

846 (4) Expected depositional features include levées and lobes.

847 (5) Expected erosional features include discrete slip scars.

848 Points 1-3 of are hard to observe or test, but the erosional and depositional features 849 can be detected in the high resolution HiRISE images. Failure scars have been noted by other 850 authors (Dickson \& Head 2009) from HiRISE images and are present within our study areas. 851 Depositional lobes have also been noted by other authors (Levy et al. 2009; Lanza et al. 852 2010). Visual observations have been made of debris flow levées (Lanza et al. 2010), but 853 DEMs from HiRISE are not yet of sufficient quality to reliably resolve debris flow levées. 854 High quality DEMs would allow the estimation of individual flow volumes (Conway et al. 855 2010b), which could be used to constrain models of gully formation. This should be a priority 856 for future work, as it would allow more accurate estimates of the amounts of water associated 857 with formation of gully landforms.

858 A debris flow, once triggered, results in more erosion and deposition with less water 859 than pure water flow. This means that high discharges, invoked by other workers (Heldmann 860 et al. 2005; Hart et al. 2009), are not required to form martian gullies. Modelling has shown 861 that surface melting produces only small amounts of liquid water (Williams et al. 2009). This 862 has been one of the major criticisms of the surface melting model. However, if gullies are 863 formed mainly by debris flow, points (1) and (2) above indicate that relatively small amounts 864 of water are needed. 


\section{Implications for the water source of martian gullies}

866 The observed relationship in slope-area plots between the slope turnover and the location of

867 gully heads in site KC on Mars is an important observation and indicates that the transition

868 from concave to convex topography is closely linked to gully formation. This would not be

869 expected in an aquifer system, as channel formation would be controlled predominantly by

870 the location of aquifer bodies rather than the shape of the landscape (Fetter 2001). Our work

871 indicates that a widely distributed source of surface or shallow subsurface flow in site KC

872 would be the most satisfactory explanation, in support of the conclusions of Lanza et al.

873 (2010). Because our data do not show a definite trend in slope-area plots this indicates that

874 the channels originate from shallow sub-surface flow (Hattanji et al. 2006; Jaeger et al. 2007;

875 Imaizumi et al. 2010), or more likely surface flow in a soil poor landscape (Larsen et al.

876 2006). A potential source for this near surface water is the mantle deposits, which have been

877 observed on both this slope and in site PC2 and has been linked to gully formation by other

878 authors (Christensen 2003; Aston et al. 2010; van Gasselt et al. 2010).

879 The development of equally spaced incised alcoves in site GC can either be

880 attributed to geological controls (e.g., faulting), or landscape self organisation from an

881 interlinked debris flow-alluvial system (Perron et al. 2009). We argue against a structural

882 control, because there is a lack of these organised alcoves on the equator-facing slope. Hence,

883 considering that we conclude debris flow to be the dominant gully forming process on this

884 crater slope, it would seem most likely that these self-organised alcoves are a result of this

885 process. This kind of self organisation requires a landscape that responds to a distributed

886 water source as on Earth rather than an aquifer source.

887 Kreslavsky \& Head (2003) and Kreslavsky et al. (2008) found that pole-facing

888 slopes between $40-50^{\circ}$ latitude in both hemispheres were systematically gentler than equator-

889 facing slopes. They suggest that this is due to insolation asymmetry and melting of ice on 
890 pole-facing slopes during periods of high obliquity, similar to the model proposed by Costard 891 et al. (2002) for gully formation on pole-facing slopes. Our study sites also show this 892 asymmetry: pole-facing slopes are longer and have a greater variety of slope angles and are 893 more concave, whereas the equator-facing slopes are shorter and have a more uniform

894 distribution of slopes and are more linear. There is a marked difference in geomorphological 895 process between crater walls with different aspects in the two craters that we studied (sites 896 PC and GC). The observed asymmetry of process and form supports the model of a climatic 897 influence on gully formation and general slope development of the craters. However, many 898 more sites would have to be studied to verify this for gullies in general.

\section{Conclusions}

900 We have shown the potential of applying quantitative geomorphological analysis techniques

901 commonly used on Earth for discriminating between different active processes on Mars.

902 Specifically we have validated the use of slope-area plots, cumulative area distribution 903 (CAD) plots, and wetness index maps on small slope sections of less than one square

904 kilometre. We have shown that pure water (alluvial) flow, debris flow and dry mass wasting 905 dominated slopes can be satisfactory discriminated on Earth. By applying these techniques to 906 four areas of Mars containing recent gullies we have inferred that debris flow is the dominant 907 gully forming process. However, we have also inferred that, as on Earth, gully formation on 908 Mars is a complex process: slopes on Mars are likely to have been affected by a variety of 909 processes that lead to a mixture of signals from our geomorphological analyses. Despite this,

910 we have not found the distinctive geomorphological fingerprint of pure water flow on slopes

911 that host gullies. Its absence, however, does not prove the absence of the process. Our results

912 are consistent with the possibility that ice driven creep and solifluction are, or have recently 913 been, active in modifying crater slopes on Mars. 
914 From the location of gully heads within the landscape, and by studying the form of

915 alcoves, it is apparent that at least two of the sites examined contain gullies which have been

916 formed from a widely distributed source of water. This is most easily explained by a surface

917 melting source for the water. The model of Costard et al. (2002) provides a mechanism by

918 which the cause of this melting was increased insolation during past high obliquity

919 excursions. Our preliminary observations of an asymmetry in process and form around the

920 impact craters provides additional support for this model, but we cannot rule out surface

921 melting at present day, or during other epochs.

922 Our geomorphological evidence for debris flow as an active process in forming 923 gullies is reinforced by visual observations. Debris flow as a process leaves distinct 924 geomorphological features, such as failure scars and lobate deposits, which have been 925 observed both here and in previous studies (Dickson \& Head 2009; Levy et al. 2009; Lanza 926 et al. 2010). Unfortunately the topographic data on Mars are not yet sufficient for the 927 discrimination of these features and flanking levées in DEMs, which would allow accurate 928 estimation of individual flow volumes and thus estimation of the volumes of water needed to 929 form the gullies (Conway et al. 2010b).

\section{Appendix 1}

931 The derivation of the shear stress erosion model relies on the assumption that erosion rate $(E)$

932 is a power law of bed shear stress $\left(\tau_{b}\right)$ :

$$
E=k \tau_{b}^{a}
$$


937 (1999) we use the assumptions of conservation of mass (water) and steady uniform flow to 938 obtain the following expression of basal shear stress:

939

940

$$
\tau_{b}=\rho C_{f}^{1 / 3}\left(\frac{g S Q}{W}\right)^{2 / 3}
$$

941

942 where $\rho$ is the density of water, $C_{f}$ is a dimensionless friction factor, $\mathrm{g}$ is the acceleration due 943 to gravity, $\mathrm{S}$ is the local channel slope, $Q$ is the stream discharge and $W$ is the stream width.

944 We then include a relationship for basin hydrology and hydraulic geometry given by:

945

946

$$
Q=k_{q} A^{c}
$$

947

$$
W=k_{w} Q^{b}
$$

948

949 where $k_{q}$ and $k_{w}$ are constants, $A$ is the drainage area and $b$ and $c$ are positive dimensionless 950 constants. Combining 2-5, leads to:

951

952

$$
E=k_{e} A^{m} S^{n}
$$

953

954 where:

955

956

$$
k_{e}=k_{b} k_{w}^{-2 a / 3} k_{q}{ }^{2 a(1-b) / 3} \rho^{a} g^{2 a / 3}
$$

957

$$
m=(2 a c / 3)(1-b)
$$

$$
n=2 a / 3
$$

959 
960 Given this, if we now define a constant $k_{m}$ for Mars, based on the assumption that gravitation

961 acceleration is approximately one third that on Earth:

962

963

$$
k_{m}=(1 / 3)^{2 a / 3} k_{e}=(1 / 3)^{n} k_{e}
$$

964

965 To derive (1), in the main text, we have to include the expectation that over long timescales,

966 uplift rate (U) and erosion rate compete to change the landscape elevation (z):

967

968

$$
\frac{\partial z}{\partial t}=U-E=U-k_{e} A^{m} S^{n}
$$

969

970

where $t$ is a given time-step. Now if we assume that the system is in equilibrium in which erosion is balanced by uplift rate, $\partial \mathrm{z} / \partial t=0$, then:

972

973

$$
S=\left(U / k_{e}\right)^{1 / n} A^{-m / n}
$$

974

975 Comparing this to equation (1), in the main text, we have:

976

977

$$
\mathrm{k}=\left(\mathrm{U} / \mathrm{k}_{\mathrm{e}}\right)^{1 / \mathrm{n}}
$$

978

$$
\theta=-m / n
$$

979

980 If we then include our $k_{m}$ constant (7) for Mars in (9) we get:

981

982

$$
S=\left(U / k_{m}\right)^{1 / n} A^{-m / n}
$$

983

$$
S=3\left(U / k_{e}\right)^{1 / n} A^{-m / n}
$$


985 Thus for a given drainage area on Earth we would expect the slope on Mars to be three times 986 smaller. Or, in log-log terms:

987

988

$$
\log S=\log 3+1 / n \log (U / k e)-m / n \log A
$$

989

\section{Acknowledgements}

991 Thanks go to Grant Meyer and one anonymous reviewer for their constructive comments 992 which greatly improved this manuscript. This work would not have been possible without a 993 postgraduate studentship grant from the U.K. Natural Environment Research Council 994 (NERC). We thank the NERC ARSF for obtaining the LiDAR data on which part of this 995 paper relies. We thank the UK NASA RPIF-3D Facility at UCL for enabling the production 996 of one of the HiRISE DEMs. Additional funding was awarded to S.J.C. by Earth and Space 997 Awards, the Geological Society’s W.G. Fearnsides Award, The Dudley Stamp Fund and the 998 British Society for Geomorphology's postgraduate funds. P.M.G. is funded by an STFC 999 Aurora Fellowship (ST/F011830/1).Thanks to Jon Yearsley for creation of spatialPattern 1000 script to create pink noise in MatLab.

1001 


\section{References}

1003

1004

1005

1006

1007

1008

1009

1010

1011

1012

1013

1014

1015

1016

1017

1018

1019

1020

1021

1022

1023

1024

1025

1026

1027

1028

1029

1030

1031

1032

1033

1034

1035

1036

1037

1038

1039

1040

1041

1042

1043

1044

1045

1046

1047

Akca, D. 2007a. Least Squares 3D Surface Matching. PhD thesis, Eidgenössische Technische Hochschule, Zürich.

Akca, D. 2007b. Matching of 3D surfaces and their intensities. ISPRS Journal of

Photogrammetry and Remote Sensing, 62, 2, 112-121.

Aston, A. H., Conway, S. J. \& Balme, M. R. 2010. Identifying Martian gully evolution. In: Balme, M., Bargery, A. S., Gallagher, C. \& Gupta, S. (eds), Geomorphology on Mars and Other Planets. The Geological Society of London, accepted.

Balme, M., Mangold, N., Baratoux, D., Costard, F., Gosselin, M., Masson, P., Pinet, P. \& Neukum, G. 2006. Orientation and distribution of recent gullies in the southern hemisphere of mars: Observations from High Resolution Stereo Camera/Mars Express (HRSC/MEX) and Mars Orbiter Camera/Mars Global Surveyor (MOC/MGS) data. Journal of Geophysical Research - Planets; , 111, E5, doi:10.1029/2005JE002607

Balme, M. R. \& Gallagher, C. 2009. An equatorial periglacial landscape on Mars. Earth and Planetary Science Letters, 285, 1-2, 1-15.

Balme, M. R., Gallagher, C. J., Page, D. P., Murray, J. B. \& Muller, J. P. 2009. Sorted stone circles in Elysium Planitia, Mars: Implications for recent martian climate. Icarus, 200, 1, 30-38.

Ben David-Novak, H., Morin, E. \& Enzel, Y. 2004. Modern extreme storms and the rainfall thresholds for initiating debris flows on the hyperarid western escarpment of the Dead Sea, Israel. Geological Society of America Bulletin, 116, 5-6, 718-728.

Blair, T. C. 1999. Cause of dominance by sheetflood vs. debris-flow processes on two adjoining alluvial fans, Death Valley, California. Sedimentology, 46, 6, 1015-1028.

Blair, T. C. 2000. Sedimentology and progressive tectonic unconformities of the sheetflooddominated Hell's Gate alluvial fan, Death Valley, California. Sedimentary Geology, 132, 3-4, 233-262.

Borga, M., Tonelli, F. \& Selleroni, J. 2004. A physically based model of the effects of forest roads on slope stability. Water Resources Research, 40, 12, 1-9.

Bourke, M. C. 2005. Alluvial Fans on Dunes in Kaiser Crater Suggest Niveo-Aeolian and Denivation Processes on Mars. Lunar and Planetary Science Conference, 36, no. 2373.

Brardinoni, F. \& Hassan, M. A. 2006. Glacial erosion, evolution of river long profiles, and the organization of process domains in mountain drainage basins of coastal British Columbia. Journal of Geophysical Research - Earth Surface, 111, 1, doi:10.1029/2005JF000358.

Brook, M. S., Kirkbride, M. P. \& Brock, B. W. 2008. Temporal constraints on glacial valley cross-profile evolution: Two Thumb Range, central Southern Alps, New Zealand. Geomorphology, 97, 1-2, 24-34.

Chandler, R. J. 1973. The Inclination of Talus, Artic Talus terraces, and Other Slopes Composed of Granular Materials. Journal of Geology, 81, 1-14.

Chevrier, V. \& Altheide, T. S. 2008. Low temperature aqueous ferric sulfate solutions on the surface of Mars. Geophysical Research Letters, 35, L22101, L22101

Christensen, P. R. 2003. Formation of recent martian gullies through melting of extensive water-rich snow deposits. Nature, 422, 6927, 45-48. 
Coe, J. A., Godt, J. W. \& Henceroth, A. J. 2002. Debris Flows along the Interstate 70 Corridor, Floyd Hill to the Arapahoe Basin Ski Area, Central Colorado - A Field Trip Guidebook. U.S. Geological Survey Open-File Report, USGS, Open-File Report 02-398.

Conway, S. J., Balme, M. R., Lamb, M. P., Towner, M. C. \& Murray, J. B. 2010a. Enhanced runout and erosion by overland flow under subfreezing and low pressure conditions: experiments and application to Mars. Icarus, in review.

Conway, S. J., Decaulne, A., Balme, M. R., Murray, J. B. \& Towner, M. C. 2010b. A new Approach to Estimating Hazard posed by Debris Flows in the Westfjords of Iceland. Geomorphology, 114, 4, 556-572.

Costard, F., Forget, F., Mangold, N. \& Peulvast, J. P. 2002. Formation of recent Martian debris flows by melting of near-surface ground ice at high obliquity. Science, 295, 5552, 110-113.

Crippen, J. R. 1979. Potential hazards from floodflows and debris movement in the Furnace Creek area, Death Valley National Monument, California-Nevada. U.S. Geological Survey Open-File Report, 79-991, USGS.

Crosta, G. B. \& Frattini, P. 2008. Rainfall-induced landslides and debris flows. Hydrological Processes, 22, 4, 473-477.

Decaulne, A., Sæmundsson \& Pétursson, O. 2005. Debris flow triggered by rapid snowmelt: A case study in the Gleiðarhjalli area, northwestern Iceland. Geografiska Annaler. Series A, Physical Geography, 87A, 4, 487-500.

Decaulne, A. \& Sæmundsson 2007. Spatial and temporal diversity for debris-flow meteorological control in subarctic oceanic periglacial environments in Iceland. Earth Surface Processes and Landforms, 32, 1971-1983.

Dickson, J. L., Head, J. W. \& Kreslavsky, M. 2007. Martian gullies in the southern midlatitudes of Mars: Evidence for climate-controlled formation of young fluvial features based upon local and global topography. Icarus, 188, 315-323.

Dickson, J. L. \& Head, J. W. 2009. The formation and evolution of youthful gullies on Mars: Gullies as the late-stage phase of Mars' most recent ice age. Icarus, 204, 1, 63-86.

Dietrich, W. E. \& Perron, J. T. 2006. The search for a topographic signature of life. Nature, 439, 7075, 411-418.

Fetter, C. W., 2001. Applied Hydrogeology. Prentice Hall, New Jersey, 598 pp.

Gaidos, E. J. 2001. Cryovolcanism and the recent flow of liquid water on Mars. Icarus, 153, 1, 218-223.

Garvin, J. B., Sakimoto, S. E. H., Schnetzler, C. \& Frawley, J. J. 1999. Global Geometric Properties of Martian Impact Craters: A Preliminary Assessment Using Mars Orbiter Laser Altimeter (MOLA). The Fifth International Conference on Mars, July 19-24, 1999, Pasadena, California, abstract no.6163.

Godt, J. W. \& Coe, J. A. 2007. Alpine debris flows triggered by a 28 July 1999 thunderstorm in the central Front Range, Colorado. Geomorphology, 84, 1-2, 80-97.

Hack, J. T. 1957. Studies of longitudinal stream profiles in Virginia and Maryland. U.S. Geological Survey Professional Paper, 294-B, 45-97.

Hancock, G. R. \& Evans, K. G. 2006. Channel head location and characteristics using digital elevation models. Earth Surface Processes and Landforms, 31, 7, 809-824.

Harris, C., Smith, J. S., Davies, M. C. R. \& Rea, B. 2008. An investigation of periglacial slope stability in relation to soil properties based on physical modelling in the geotechnical centrifuge. Geomorphology, 93, 3-4, 437-459.

Harris, S. A. \& Gustafson, C. A. 1993. Debris flow characteristics in an area of continuous permafrost, St. Elias Range, Yukon Territory. Zeitschrift für Geomorphologie,, 37, 1, 41-56. 
Hart, S. D., Gulick, V. C., Parsons, R. A. \& Barnhart, C. J. 2009. Gully Slopes and Discharges on Lyot Crater's Central Peak. Lunar and Planetary Science Conference, 40, no. 2349.

Hattanji, T., Onda, Y. \& Matsukura, Y. 2006. Thresholds for bed load transport and channel initiation in a chert area in Ashio Mountains, Japan: An empirical approach from hydrogeomorphic observations. Journal of Geophysical Research - Earth Surface, 111, 2, doi:10.1029/2004JF000206.

Hecht, M. H. 2002. Metastability of liquid water on Mars. Icarus, 156, 2, 373-386.

Heldmann, J. L. \& Mellon, M. T. 2004. Observations of martian gullies and constraints on potential formation mechanisms. Icarus, 168, 2, 285-304.

Heldmann, J. L., Toon, O. B., Pollard, W. H., Mellon, M. T., Pitlick, J., McKay, C. P. \& Andersen, D. T. 2005. Formation of Martian gullies by the action of liquid water flowing under current Martian environmental conditions. Journal of Geophysical Research - Planets, 110, E5, doi:10.1029/2004JE002261.

Heldmann, J. L., Carlsson, E., Johansson, H., Mellon, M. T. \& Toon, O. B. 2007. Observations of martian gullies and constraints on potential formation mechanisms II. The northern hemisphere. Icarus, 188, 324-344.

Heldmann, J. L., Conley, C., Brown, A. J., Fletcher, L., Bishop, J. L. \& McKay, C. P. 2010. Possible Liquid Water Origin for Atacama Desert Mudflow and Recent Gully Deposits on Mars. Icarus, 206, 2, 685-690.

Imaizumi, F., Hattanji, T. \& Hayakawa, Y. S. 2010. Channel initiation by surface and subsurface flows in a steep catchment of the Akaishi Mountains, Japan. Geomorphology, 115, 1-2, 32-42.

Innes, J. L. 1983. Debris Flows. Progress in Physical Geography, 7, 469-501.

Iverson, R. M. 1997. The physics of debris flows. Reviews of Geophysics, 35, 3, 245-296.

Jack, J. L. 2000. Red-shifts and red herrings in geographical ecology. Ecography, 23, 1, 101113.

Jaeger, K. L., Montgomery, D. R. \& Bolton, S. M. 2007. Channel and perennial flow initiation in headwater streams: Management implications of variability in source-area size. Environmental Management, 40, 5, 775-786.

Kirk, R. L., Howington-Kraus, E., Rosiek, M. R., Anderson, J. A., Archinal, B. A., Becker, K. J., Cook, D. A., Galuszka, D. M., Geissler, P. E., Hare, T. M., Holmberg, I. M., Keszthelyi, L. P., Redding, B. L., Delamere, W. A., Gallagher, D., Chapel, J. D., Eliason, E. M., King, R. \& McEwen, A. S. 2008. Ultrahigh resolution topographic mapping of Mars with MRO HiRISE stereo images: Meter-scale slopes of candidate Phoenix landing sites. Journal of Geophysical Research - Planets, 113, doi:10.1029/2007JE003000.

Kirkby, M. J., Bull, L. J., Poesen, J., Nachtergaele, J. \& Vandekerckhove, L. 2003. Observed and modelled distributions of channel and gully heads - with examples from SE Spain and Belgium. Catena, 50, 2-4, 415-434.

Kneissl, T., Reiss, D., van Gasselt, S. \& Neukum, G. 2009. Distribution and orientation of northern-hemisphere gullies on Mars from the evaluation of HRSC and MOC-NA data. Earth and Planetary Science Letters, In Press, Corrected Proof.

Kobor, J. S. \& Roering, J. J. 2004. Systematic variation of bedrock channel gradients in the central Oregon Coast Range: Implications for rock uplift and shallow landsliding. Geomorphology, 62, 3-4, 239-256.

Kolb, K. J., Pelletier, J. D. \& McEwen, A. S. 2010. Modeling the formation of bright slope deposits associated with gullies in Hale Crater, Mars: Implications for recent liquid water. Icarus, 205, 1, 113-137. 
Kreslavsky, M. A. \& Head, J. W. 2003. North-south topographic slope asymmetry on Mars: Evidence for insolation-related erosion at high obliquity. Geophysical Research Letters, 30, 15, doi:10.1029/2003GL017795.

Kreslavsky, M. A., Head, J. W. \& Marchant, D. R. 2008. Periods of active permafrost layer formation during the geological history of Mars: Implications for circum-polar and mid-latitude surface processes. Planetary and Space Science, 56, 2, 289-302.

Lague, D. \& Davy, P. 2003. Constraints on the long-term colluvial erosion law by analyzing slope-area relationships at various uplift rates in the Siwaliks Hills (Nepal). Journal of Geophysical Research - Solid Earth, 108, 2, doi:10.1029/2002JB001893.

Lanza, N. L., Meyer, G. A., Okubo, C. H., Newsom, H. E. \& Wiens, R. C. 2010. Evidence for debris flow gully formation initiated by shallow subsurface water on Mars. Icarus, 205, 1, 103-112.

Larsen, I. J., Pederson, J. L. \& Schmidt, J. C. 2006. Geologic versus wildfire controls on hillslope processes and debris flow initiation in the Green River canyons of Dinosaur National Monument. Geomorphology, 81, 1-2, 114-127.

Levy, J. S., Head, J. W., Dickson, J. L., Fassett, C. I., Morgan, G. A. \& Schon, S. C. 2009. Identification of gully debris flow deposits in Protonilus Mensae, Mars: Characterization of a water-bearing, energetic gully-forming process. Earth and Planetary Science Letters, In Press, Corrected Proof.

Malin, M. C. \& Edgett, K. S. 2000. Evidence for recent groundwater seepage and surface runoff on Mars. Science, 288, 5475, 2330-2335.

Malin, M. C., Edgett, K. S., Posiolova, L. V., McColley, S. M. \& Dobrea, E. Z. N. 2006. Present-day impact cratering rate and contemporary gully activity on Mars. Science, 314, 5805, 1573-1577.

Mangeney, A., Bouchut, F., Thomas, N., Vilotte, J. P. \& Bristeau, M. O. 2007. Numerical modeling of self-channeling granular flows and of their levee-channel deposits. Journal of Geophysical Research - Earth Surface, 112, 2, doi:10.1029/2006JF000469.

Mangold, N. 2005. High latitude patterned grounds on Mars: Classification, distribution and climatic control. Icarus, 174, 336-359.

Mao, L., Cavalli, M., Comiti, F., Marchi, L., Lenzi, M. A. \& Arattano, M. 2009. Sediment transfer processes in two Alpine catchments of contrasting morphological settings. Journal of Hydrology, 364, 1-2, 88-98.

Marchi, L., Dalla Fontana, G., Cavalli, M. \& Tagliavini, F. 2008. Rocky headwaters in the Dolomites, Italy: Field observations and topographic analysis. Arctic Antarctic and Alpine Research, 40, 4, 685-694.

McEwen, A. S., Hansen, C. J., Delamere, W. A., Eliason, E. M., Herkenhoff, K. E., Keszthelyi, L., Gulick, V. C., Kirk, R. L., Mellon, M. T., Grant, J. A., Thomas, N., Weitz, C. M., Squyres, S. W., Bridges, N. T., Murchie, S. L., Seelos, F., Seelos, K., Okubo, C. H., Milazzo, M. P., Tornabene, L. L., Jaeger, W. L., Byrne, S., Russell, P. S., Griffes, J. L., MartÃ-nez-Alonso, S., Davatzes, A., Chuang, F. C., Thomson, B. J., Fishbaugh, K. E., Dundas, C. M., Kolb, K. J., Banks, M. E. \& Wray, J. J. 2007. A closer look at water-related geologic activity on Mars. Science, 317, 5845, 1706-1709.

McNamara, J. P., Ziegler, A. D., Wood, S. H. \& Vogler, J. B. 2006. Channel head locations with respect to geomorphologic thresholds derived from a digital elevation model: A case study in northern Thailand. Forest Ecology and Management, 224, 1-2, 147-156.

Miller, D. J. 1961. Geology of the Katalla district, Gulf of Alaska Tertiary province, Alaska. U.S. Geological Survey Open-File Report.

Montgomery, D. R. \& Foufoula-Georgiou, E. 1993. Channel network source representation using digital elevation models. Water Resources Research, 29, 12, 3925-3934. 
Moore, H. J. \& Jakosky, B. M. 1989. Viking landing sites, remote-sensing observations, and physical properties of Martian surface materials. Icarus, 81, 164-184.

Morton, D. M., Alvarez, R. M., Ruppert, K. R. \& Goforth, B. 2008. Contrasting rainfall generated debris flows from adjacent watersheds at Forest Falls, southern California, USA. Geomorphology, 96, 3-4, 322-338.

Moyle, W. R. 1982. Water Resources of Borrego Valley and Vicinity, California: Phase 1 Definition of Geologic and Hydrologic Characteristics of a Basin. U.S. Geological Survey Open-File Report, 82-855, USGS.

Musselwhite, D. S., Swindle, T. D. \& Lunine, J. I. 2001. Liquid $\mathrm{CO}_{2}$ breakout and the formation of recent small gullies on Mars. Geophysical Research Letters, 28, 7, 1283 1285.

Mustard, J. F., Cooper, C. D. \& Rifkin, M. K. 2001. Evidence for recent climate change on Mars from the identification of youthful near-surface ground ice. Nature, 412, 6845, 411-414.

Norðdalh, H. 1990. Late Weichselian and early Holocene deglaciation history of Iceland. Jökull, 40, 27-50.

Pelletier, J. D., Kolb, K. J., McEwen, A. S. \& Kirk, R. L. 2008. Recent bright gully deposits on Mars: Wet or dry flow? Geology, 36, 3, 211-214.

Perera, H. \& Willgoose, G. 1998. A physical explanation of the cumulative area distribution curve. Water Resources Research, 34, 5, 1335-1343.

Perron, J. T., Dietrich, W. E., Howard, A. D., McKean, J. A. \& Pettinga, J. R. 2003. Icedriven creep on Martian debris slopes. Geophysical Research Letters, 30, 14, doi:10.1029/2003GL017603.

Perron, J. T., Kirchner, J. W. \& Dietrich, W. E. 2009. Formation of evenly spaced ridges and valleys. Nature, 460, 7254, 502-505.

Peters, G. H., Abbey, W., Bearman, G. H., Mungas, G. S., Smith, J. A., Anderson, R. C., Douglas, S. \& Beegle, L. W. 2008. Mojave Mars simulant--Characterization of a new geologic Mars analog. Icarus, 197, 2, 470-479.

Reiss, D., van Gasselt, S., Neukum, G. \& Jaumann, R. 2004. Absolute dune ages and implications for the time of formation of gullies in Nirgal Vallis, Mars. Journal of Geophysical Research - Planets, 109, E6, doi:10.1029/2004JE002251.

Schon, S. C., Head, J. W. \& Fassett, C. I. 2009. Unique chronostratigraphic marker in depositional fan stratigraphy on Mars: Evidence for ca. 1.25 Ma gully activity and surficial meltwater origin. Geology, 37, 3, 207-210.

Selby, M. J., 1993. Hillslope Materials and Processes. Oxford University Press, Oxford, 451 pp.

Shinbrot, T., Duong, N. H., Kwan, L. \& Alvarez, M. M. 2004. Dry granular flows can generate surface features resembling those seen in Martian gullies. Proceedings of the National Academy of Sciences of the United States of America, 101, 23, 8542-8546.

Sirkin, L. \& Tuthill, S. J. 1987. Late Pleistocene and Holocene deglaciation and environments of the southern Chugach Mountains, Alaska. Geological Society of America Bulletin, 99, 376-384.

Snyder, N. P., Whipple, K. X., Tucker, G. E. \& Merritts, D. J. 2000. Landscape response to tectonic forcing: Digital elevation model analysis of stream profiles in the Mendocino triple junction region, Northern California. Bulletin of the Geological Society of America, 112, 8, 1250-1263.

Soare, R. J. \& Osinski, G. R. 2009. Stratigraphical evidence of late Amazonian periglaciation and glaciation in the Astapus Colles region of Mars. Icarus, 202, 17-21.

Stock, J. \& Dietrich, W. E. 2003. Valley incision by debris flows: Evidence of a topographic signature. Water Resources Research, 39, 4, doi:10.1029/2001WR001057. 
Stock, J. D. \& Dietrich, W. E. 2006. Erosion of steepland valleys by debris flows. Bulletin of the Geological Society of America, 118, 9-10, 1125-1148.

Tarboton, D. G., Bras, R. L. \& Rodriguez-Iturbe, I. 1991. On the extraction of channel networks from digital elevation data. Hydrological Processes, 5, 1, 81-100.

Tarboton, D. G. 1997. A new method for the determination of flow directions and upslope areas in grid digital elevation models. Water Resources Research, 33, 2, 309-319.

Tarolli, P. \& Fontana, G. D. 2009. Hillslope-to-valley transition morphology: New opportunities from high resolution DTMs. Geomorphology, 113, 1-2, 47-56.

Treiman, A. H. 2003. Geologic settings of Martian gullies: Implications for their origins. Journal of Geophysical Research - Planets; , 108, E4, doi:10.1029/2002JE001900.

Tucker, G. E. \& Bras, R. L. 1998. Hillslope processes, drainage density, and landscape morphology. Water Resources Research, 34, 10, 2751-2764.

van Gasselt, S., Hauber, E., Pio Rossi, A., Dumke, A., Orosei, R. \& Neukum, G. 2010. Periglaical Geomorphology of Tempe Terra, Mars: role of mantling deposits in lobate debris apron formation and evolution. In: Balme, M., Bargery, A. S., Gallagher, C. \& Gupta, S. (eds), Geomorphology on Mars and Other Planets. The Geological Society of London, in review.

Whipple, K. X. \& Tucker, G. E. 1999. Dynamics of the stream-power river incision model: Implications for height limits of mountain ranges, landscape response timescales, and research needs. Journal of Geophysical Research - Solid Earth, 104, B8, 1766117674.

Williams, K. E., Toon, O. B., Heldmann, J. L. \& Mellon, M. T. 2009. Ancient melting of mid-latitude snowpacks on Mars as a water source for gullies. Icarus, 200, 2, 418425.

Woods, R. A. \& Sivapalan, M. 1997. A connection between topographically driven runoff generation and channel network structure. Water Resources Research, 33, 12, 29392950.

Workman, J. B., Menges, C. M., Page, W. R., Taylor, E. M., Ekren, E. B., Rowley, P. D., Dixon, G. L., Thompson, R. A. \& Wright, L. A. 2002. Geologic map of the Death Valley ground-water model area, Nevada and California, Miscellaneous Field Studies Map 2381-A. USGS.

Yetemen, O., Istanbulluoglu, E. \& Vivoni, E. R. 2010. The implications of geology, soils, and vegetation on landscape morphology: Inferences from semi-arid basins with complex vegetation patterns in Central New Mexico, USA. Geomorphology, 116, 3-4, 246-263. 


\section{Figure Captions}

1286 Fig. 1. HiRISE images of a variety of gullies on Mars. Image credits: NASA/JPL/UofA. (a)

1287 Gullies on the wall of a small impact crater within Kaiser Crater, site KC in this study, image

1288 number: PSP_003418_1335, at $18.8^{\circ} \mathrm{E}, 54.3^{\circ} \mathrm{S}$. (b) Gullies within a polar pit, image number:

1289 PSP_003498_1090 at $1.6^{\circ} \mathrm{E}, 70.6^{\circ} \mathrm{S}$. (c) Gullies on the wall of Galap Crater, near Sirenum

1290 Fossae, image number: PSP_003939_1420, at $192.9^{\circ} \mathrm{E}, 37.7^{\circ} \mathrm{S}$. (d) Gullies on the wall of

1291 Wirtz Crater, a large impact crater to the east of Argyre basin, image number:

1292 PSP_002457_1310, at $335.3^{\circ} \mathrm{E}, 48.2^{\circ} \mathrm{S}$. (e) Gullies on the slip face of dunes in Russell Crater,

1293 located in Noachis Terra, image number: PSP_001440_1255, at $12.9^{\circ}$ E, 54.2 ${ }^{\circ}$ S. (f) Gullies on

1294 the wall of an impact crater to the west of Newton Crater in Terra Sirenum, image number:

1295 PSP_005930_1395, at $196.8^{\circ} \mathrm{E}, 40.3^{\circ} \mathrm{S}$.

1296

1297 Fig. 2. Slope-area and Cumulative Area Distribution (CAD) plots, showing typical process 1298 domains on Earth. (a) Slope-area plot from Montgomery \& Foufoula-Georgiou (1993) with 1299 the additional domain of Brardinoni \& Hassan (2006) indicated with a dashed line. The 1300 arrows and dotted line indicate the adjustment to the alluvial domain boundary considering 1301 the gravitational acceleration of Mars. (b) CAD plot from McNamara et al. (2006). P(A>A*) 1302 represents the probability of a point in the landscape having a drainage area greater than the 1303 given drainage area, $\mathrm{A}^{*}$, on the $\mathrm{x}$-axis. Region 1a represents hillslopes that diverge and do 1304 not gather drainage. Region 1b represents hillslopes with convergent topography. Region 1c 1305 represents pore-pressure triggered landsliding or debris flow. Region 2 represents incision, or 1306 channel formation. Region 3 has large steps where large tributaries join the channel. 
1308 Fig. 3. Hillshade representations made from digital elevation models of the study site 1309 locations on Earth. Areas included in this study are outlined and labelled in the Figure. (a) 1310 and (b) Site SJ, San Jacinto, California. (c) Site DV, Death Valley, California. (d) Site KA, St

1311 Elias Mountains, Alaska. (e) and (f) Site FR, Front Range, Colorado. (g) and (h) Site WF, 1312 Westfjords, NW Iceland.

1314 Fig. 4. Hillshade representations made from digital elevation models of the study site 1315 locations on Mars. Areas included in this study are outlined and labelled in the Figure. (a) and 1316 (b) Site PC, Penticton Crater in Eastern Hellas. (c), (d) and (e) Site GC, Gasa Crater in Terra 1317 Cimmeria.(f) Site KC, a crater inside Kaiser Crater in Noachis Terra. (g) Site TS, a crater in 1318 Terra Sirenum. (h) The $10 \mathrm{~km}$ diameter synthetic crater, in which the square area is where the 1319 pink noise has been applied.

1321 Fig. 5. Close-up views of gullies in Kaiser Crater (site KC), subset of HiRISE image 1322 PSP_003418_1335. Image credits: NASA/JPL/UofA. (a) Examples of gullyheads identified 1323 for individual slope-area analysis, marked by circles containing white crosses. (b) Levées 1324 interior to a channel, arrows point to levées within the channel on each side. (c) Single leveed 1325 channel, arrows point to the more obvious levee on the right, but there is an indication that 1326 there is another on the left as well.

1328 Fig. 6. Slope-area plots for the study areas on Earth. Marked with solid grey lines are the 1329 domains of Montgomery \& Foufoula-Georgiou (1993) and Brardinoni \& Hassan (2006), as 1330 shown in Fig. 2a. Labels are included in (a), but omitted for clarity in the other plots and are 1331 as follows: (i) hillslopes domain, (ii) debris flow dominated channels, (iii) unchanneled 1332 valleys, (iv) alluvial channels and (v) debris flow deposition domain. The horizontal dotted 
1333 line represents the threshold for unconsolidated dry mass wasting at 0.7 gradient, which is 1334 equivalent to $35^{\circ}$ slope.

1335 (a) Plots for those areas dominated by talus and creep processes. (b) Plots for those areas 1336 dominated by debris flow, with some influence from talus processes. (c) Plots for those areas 1337 dominated by debris flow, with influence from alluvial processes. (d) Plots for those areas 1338 dominated by ephemeral water flow, or alluvial processes.

1339

1340 Fig. 7. Cumulative Area Distribution plots for the study areas on Earth. (a) Plots for those 1341 areas dominated by talus and creep processes. (b) Plots for those areas dominated by debris 1342 flow, with some influence from talus processes. (c) Plots for those areas dominated by debris 1343 flow, with influence from alluvial processes. (d) Plots for those areas dominated by 1344 ephemeral water flow, or alluvial processes.

1346 Fig. 8. Slope-area plots for the study areas on Mars. Marked with solid grey lines are the 1347 domains of Montgomery \& Foufoula-Georgiou (1993) and Brardinoni \& Hassan (2006), as 1348 shown in Fig. 2a. Labels are included in (a), but omitted for clarity in the other plots and are 1349 as follows: (i) hillslopes domain, (ii) debris flow dominated channels, (iii) unchanneled 1350 valleys, (iv) alluvial channels and (v) debris flow deposition domain. The horizontal dotted 1351 line represents the threshold for unconsolidated dry mass wasting at 0.7 gradient, which is 1352 equivalent to $35^{\circ}$ slope. The dash-dot line represents the adjustment of the alluvial domain 1353 when taking into account Mars’ gravitational acceleration. (a) Plots for Site PC, Penticton 1354 Crater in Eastern Hellas. (b) Plots for Site GC, Gasa Crater in Terra Cimmeria. (b) Plots for 1355 Site KC, a crater inside Kaiser Crater in Noachis Terra. (d) Plots for Site TS, a crater in Terra 1356 Sirenum and the $10 \mathrm{~km}$ diameter synthetic crater. 
1358 Fig. 9. Cumulative Area Distribution plots for the study areas on Mars. (a) Plots for Site PC,

1359 Penticton Crater in Eastern Hellas. (b) Plots for Site GC, Gasa Crater in Terra Cimmeria. (b)

1360 Plots for Site KC, a crater inside Kaiser Crater in Noachis Terra. (d) Plots for Site TS, a crater

1361 in Terra Sirenum and the $10 \mathrm{~km}$ diameter synthetic crater.

1362

1363 Fig. 10. Wetness index maps made from digital elevation models of the study site locations 1364 on Earth. Areas included in this study are outlined and labelled in the Figure. Wetness index 1365 values are represented by the same colours in Fig. 11 to allow direct comparison. (a) and (b) 1366 Site SJ, San Jacinto, California. (c) Site DV, Death Valley, California. (d) Site KA, St Elias 1367 Mountains, Alaska. (e) and (f) Site FR, Front Range, Colorado. (g) and (h) Site WF, 1368 Westfjords, NW Iceland.

Fig. 11. Wetness index maps made from digital elevation models of the study site locations on Mars. Areas included in this study are outlined and labelled in the Figure. Wetness index values are represented by the same colours in Fig. 10 to allow direct comparison. (a) and (b)

1373 Site PC, Penticton Crater in Eastern Hellas. (c), (d) and (e) Site GC, Gasa Crater in Terra 1374 Cimmeria.(f) Site KC, a crater inside Kaiser Crater in Noachis Terra. (g) Site TS, a crater in 1375 Terra Sirenum. (h) 10 km diameter synthetic crater. 
(c)
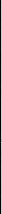
(d)

(e)
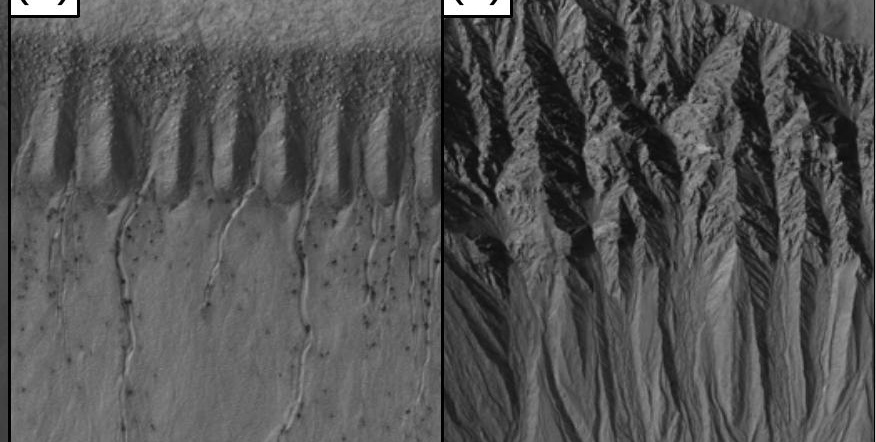

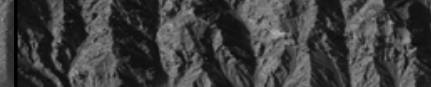

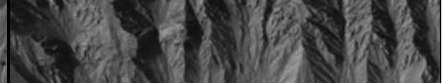
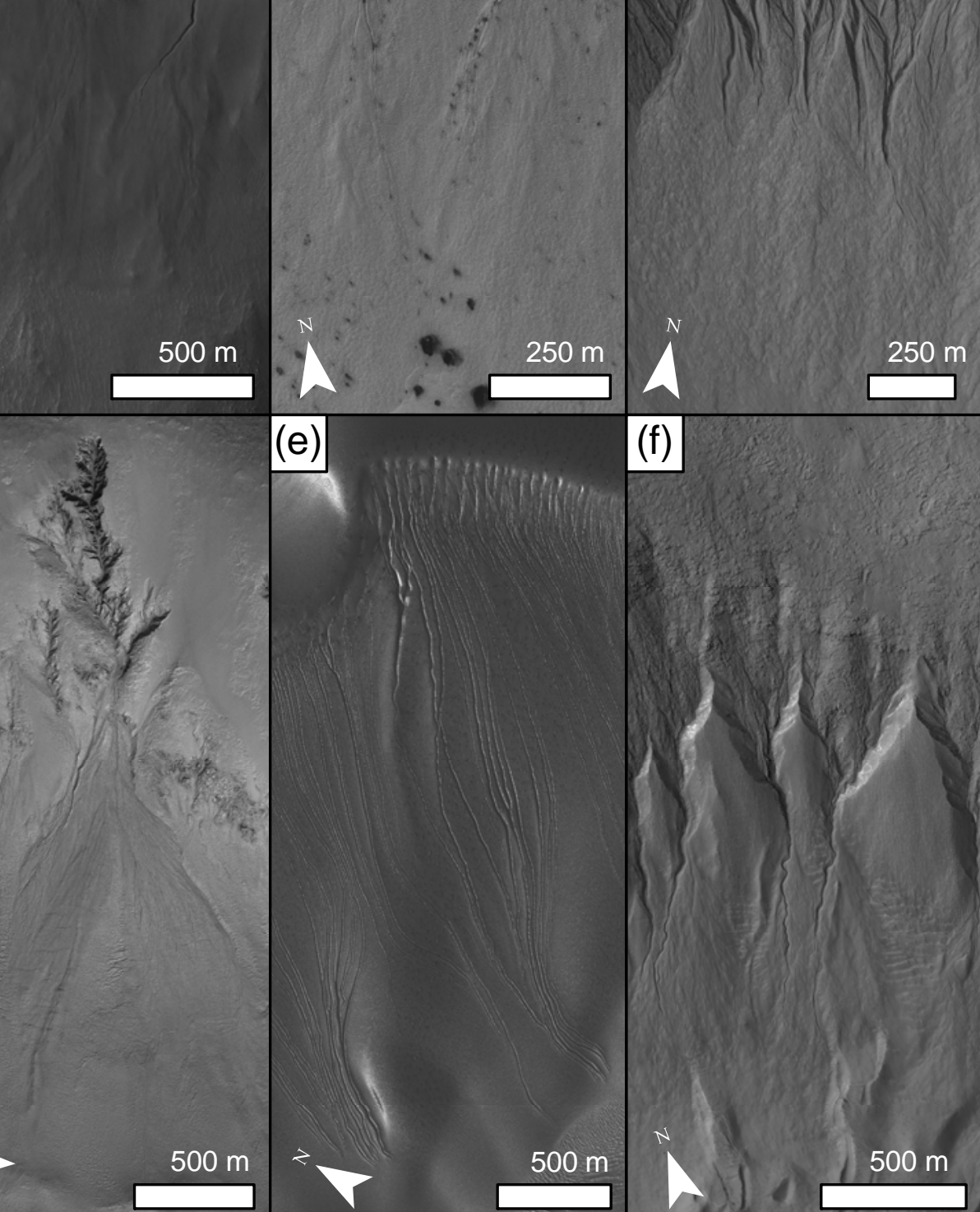

4

$500 \mathrm{~m}$

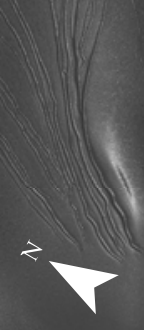

$500 \mathrm{~m}$

5

$500 \mathrm{~m}$ 
(a)

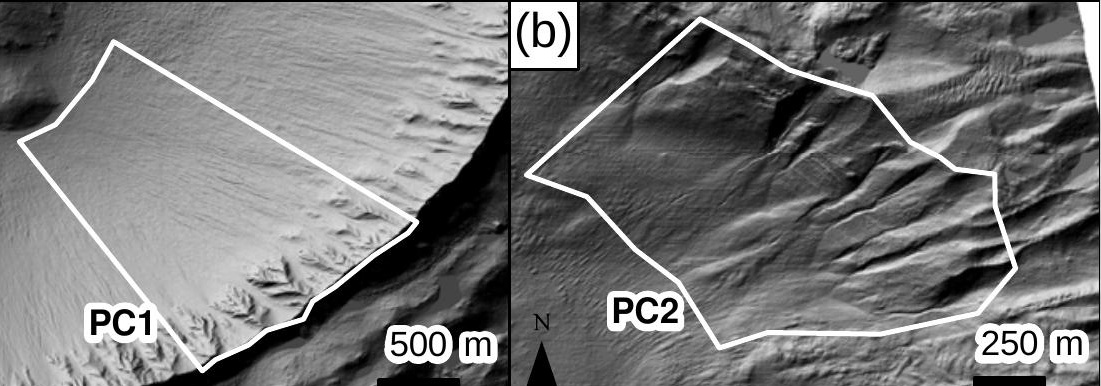

(c)

(c)

)

4 (4) GC1

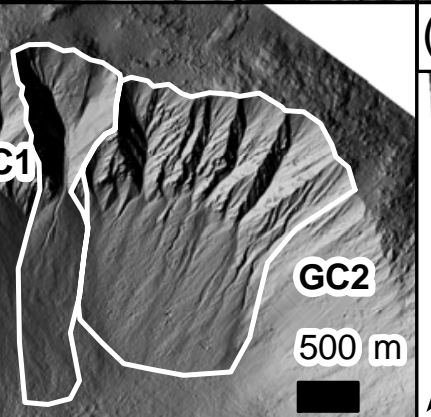

(d) s.t.
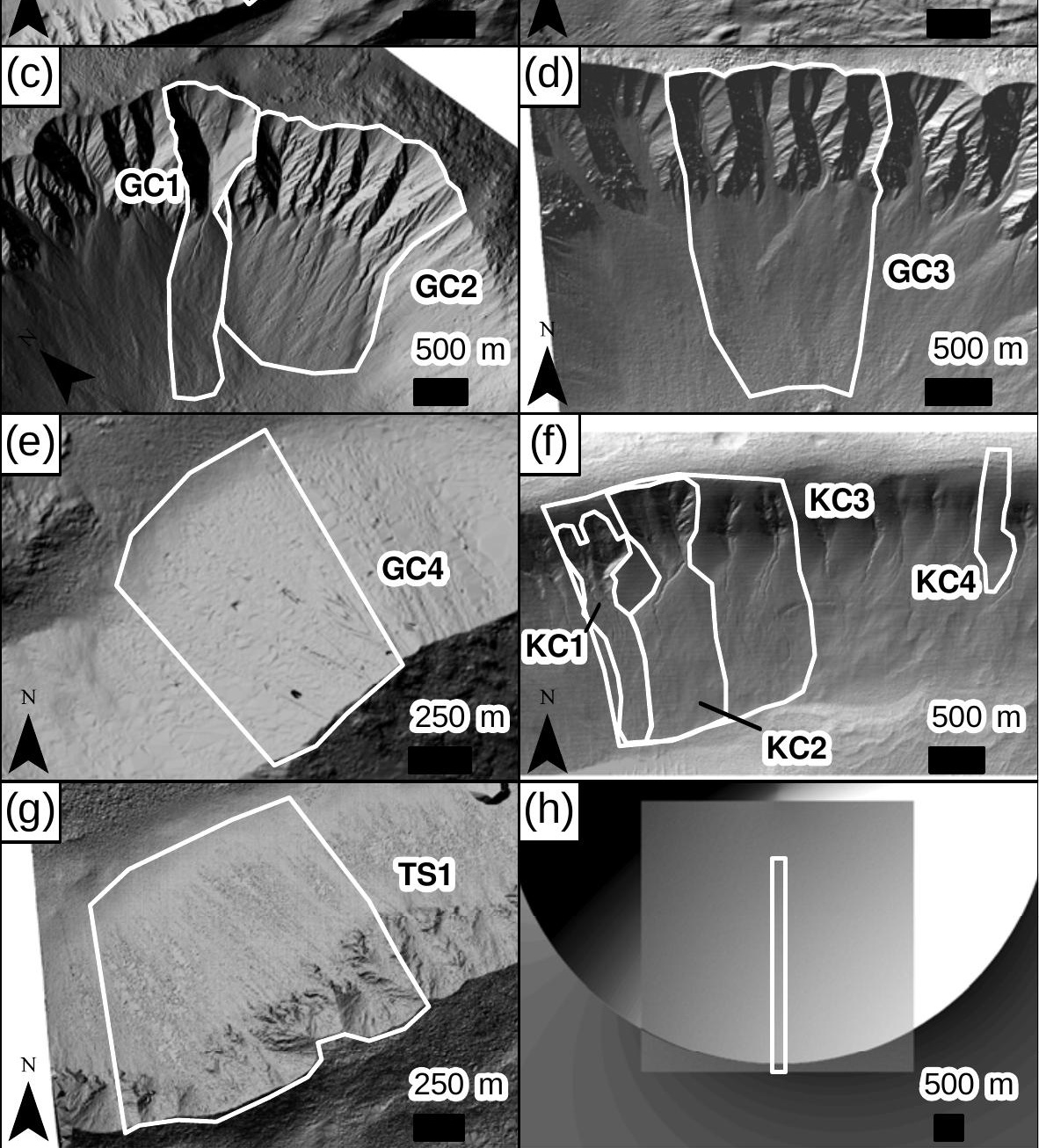
(b)

$\theta \theta$

$10 \mathrm{~m}$

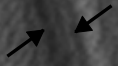

$\theta$

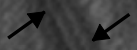

$100 \mathrm{~m}$

$10 \mathrm{~m}$ 


\section{Drainage Area $\left(\mathrm{km}^{2}\right)$}
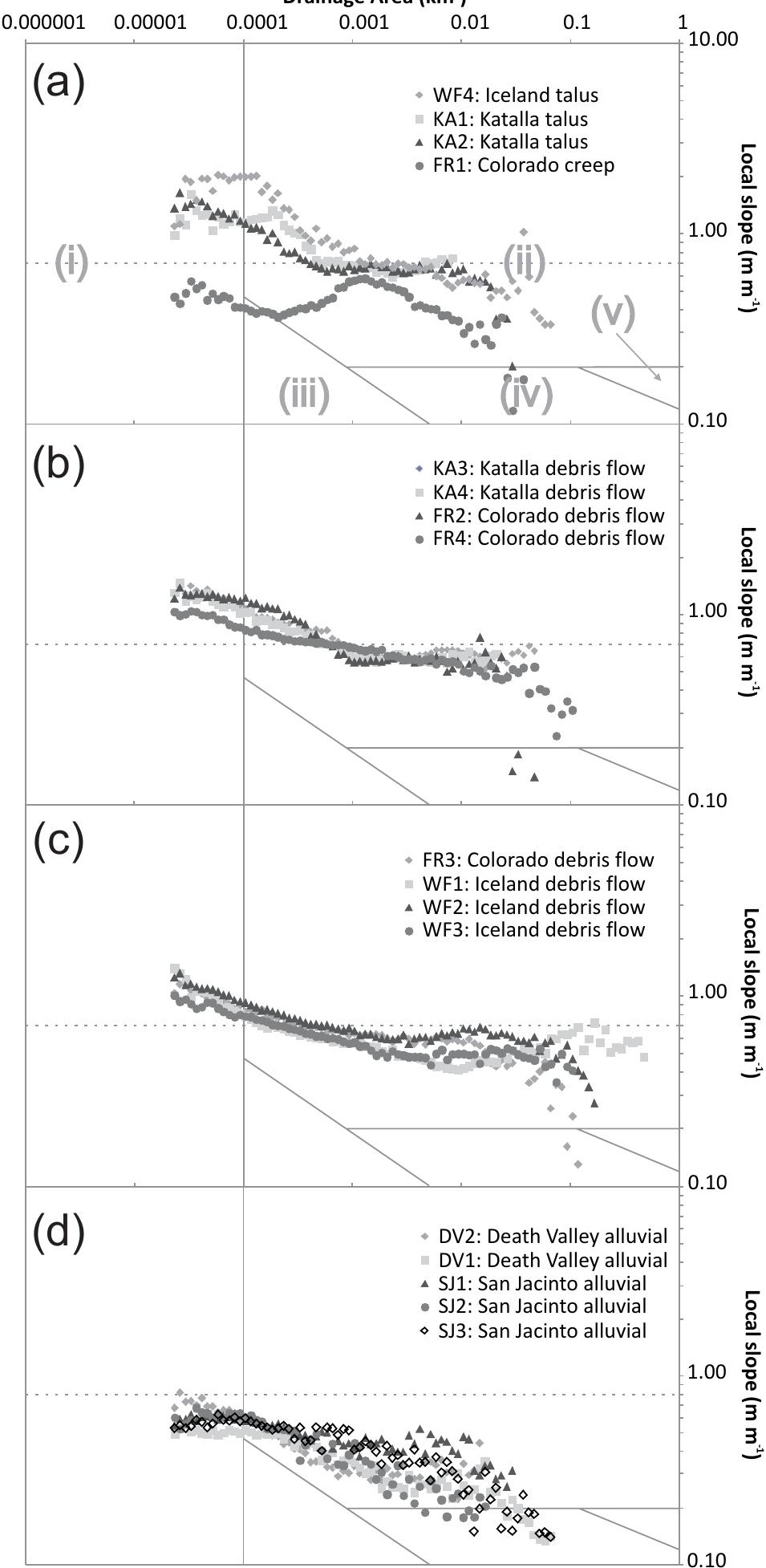


\section{Drainage Area $\left(\mathrm{km}^{2}\right)$

- WF4: Iceland talus

- KA1: Katalla talus

$\triangle$ KA2: Katalla talus

- FR1: Colorado creep
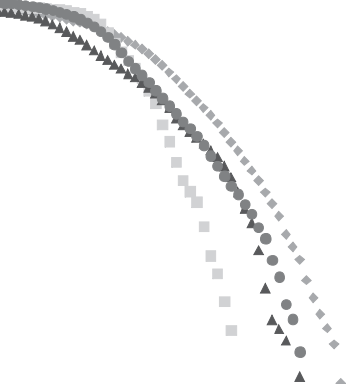

0.0010

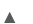

1.0000

1.0000

(b)

- KA3: Katalla debris flow

- KA4: Katalla debris flow

$\triangle$ FR2: Colorado debris flow

- FR4: Colorado debris flow

- FR3: Colorado debris flow

-WF1: Iceland debris flow

$\triangle$ WF2: Iceland debris flow

- WF3: Iceland debris flow

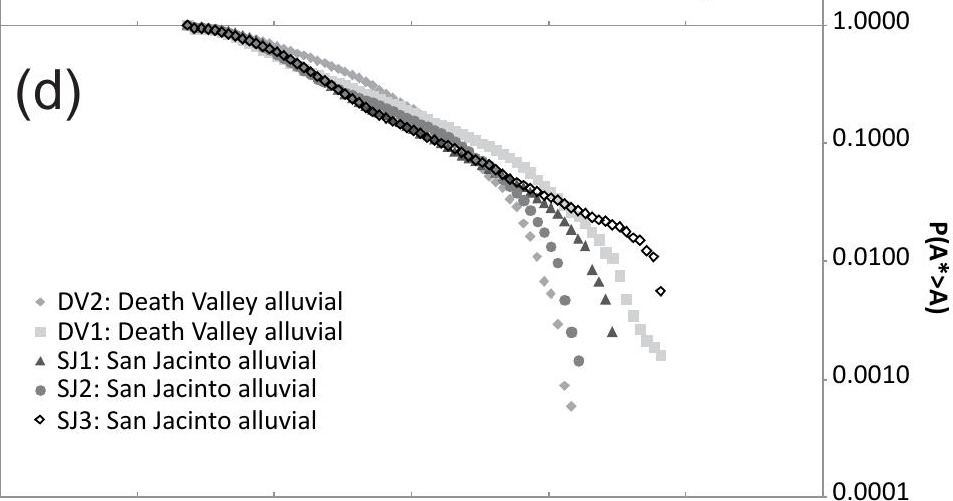




\section{Drainage Area $\left(\mathrm{km}^{2}\right)$}

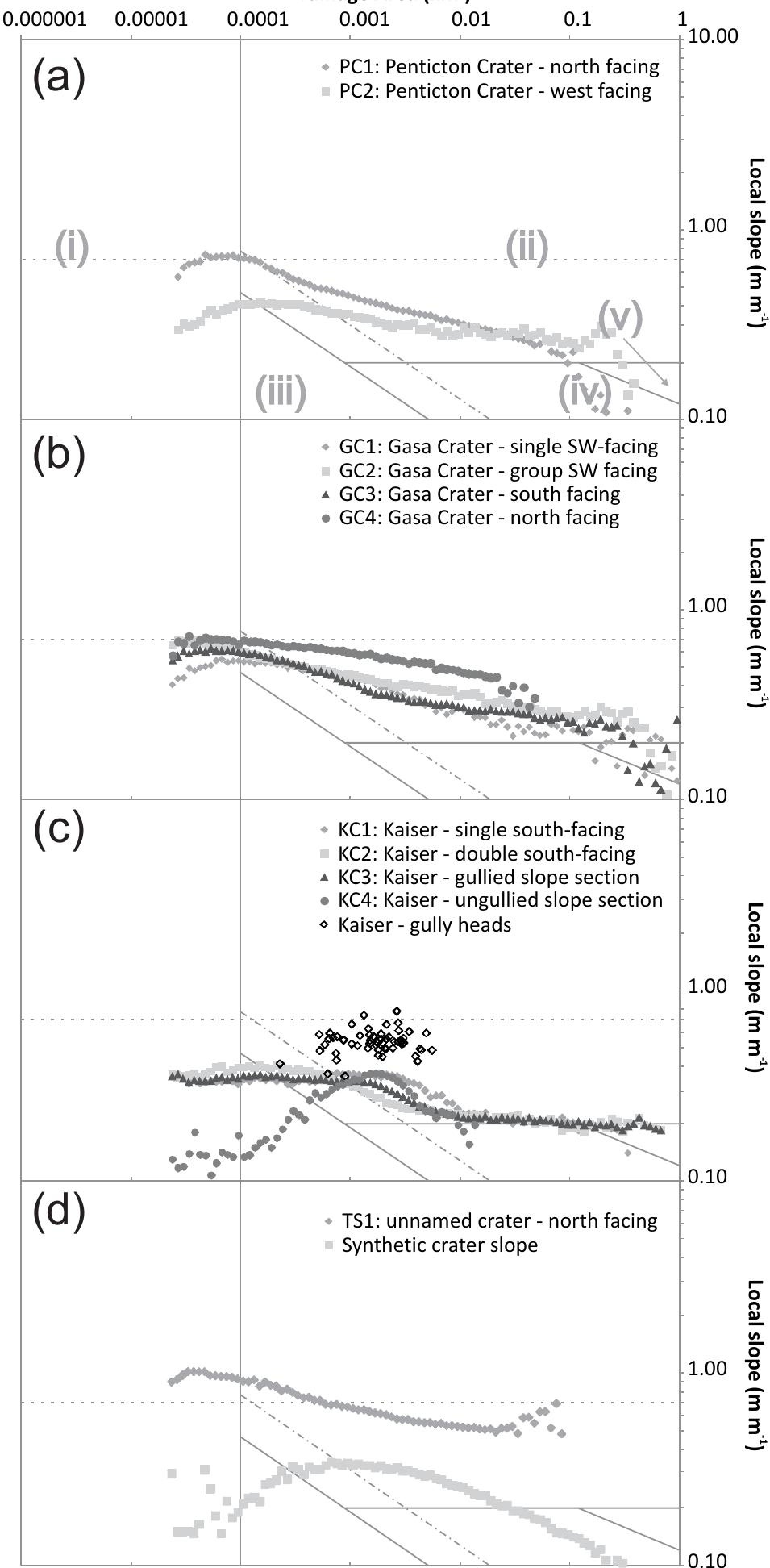




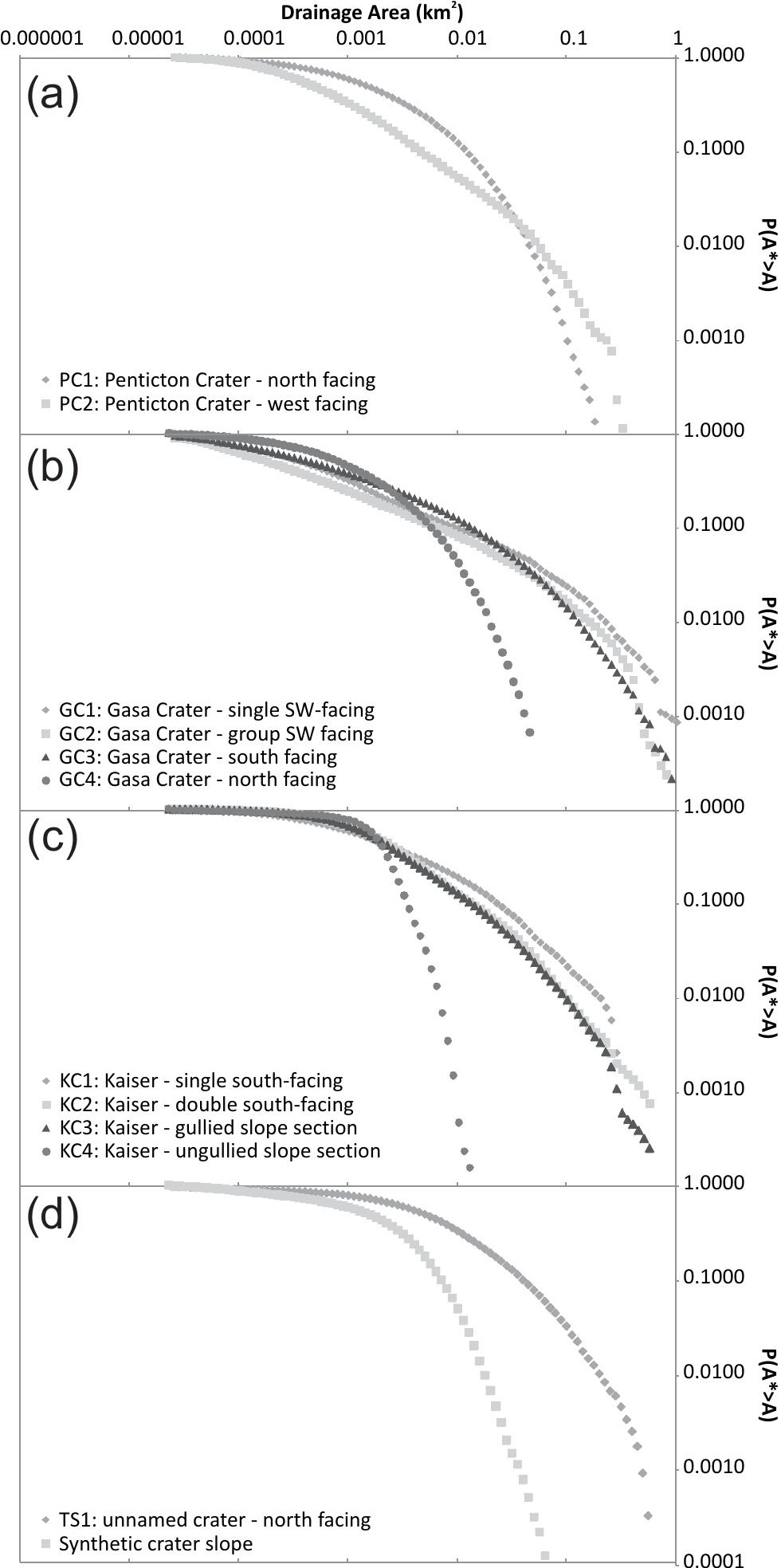


Table 1. Summary table for the study sites on Earth

\begin{tabular}{|c|c|c|c|c|c|c|c|c|c|}
\hline$\stackrel{\mathscr{0}}{\circ}$ & 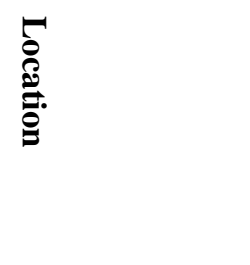 & 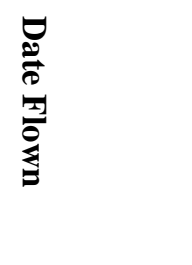 & 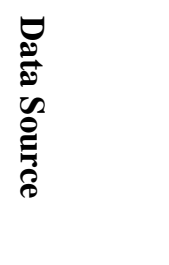 & 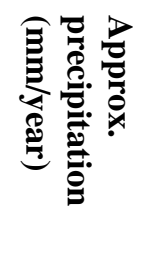 & 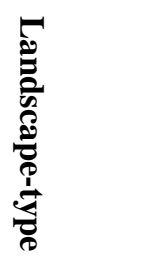 & 章 & 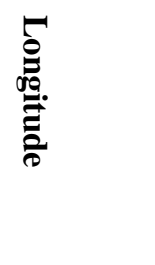 & 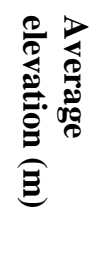 & 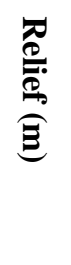 \\
\hline A & $\begin{array}{l}\text { San Jacinto Fault } \\
\text { (SJF Segment 3) - } \\
\text { Santa Rosa } \\
\text { Mountains }\end{array}$ & mid 2005 & $\begin{array}{l}\text { NCALM } \\
\text { B4 Project }\end{array}$ & 150 & desert & $\begin{array}{l}33^{\circ} 25^{\prime} \\
58.55^{\prime \prime} \mathrm{N}\end{array}$ & $\begin{array}{l}116^{\circ} 28^{\prime} \\
57.55^{\prime \prime} \mathrm{W}\end{array}$ & 597 & 677 \\
\hline B & $\begin{array}{l}\text { Death Valley } \\
\text { California }\end{array}$ & 28/02/2005 & NCALM & $<85$ & desert & $\begin{array}{l}39^{\circ} 38^{\prime} \\
01.77^{\prime \prime} \mathrm{N}\end{array}$ & $\begin{array}{l}105^{\circ} 49^{\prime} \\
13.88^{\prime \prime} \mathrm{W}\end{array}$ & 3664 & $\begin{array}{l}134 \\
5\end{array}$ \\
\hline C & St. Elias, Alaska & 02-15/9/2005 & NCALM & 2000 & periglacial & $\begin{array}{l}60^{\circ} 18^{\prime} \\
18.59^{\prime \prime} \mathrm{N}\end{array}$ & $\begin{array}{l}144^{\circ} 32^{\prime} \\
14.98^{\prime \prime} \mathrm{W}\end{array}$ & 490 & 831 \\
\hline D & $\begin{array}{l}\text { Front Range, } \\
\text { Colorado }\end{array}$ & $30 / 09 / 2005$ & NCALM & 600 & periglacial & $\begin{array}{l}37^{\circ} 04^{\prime} \\
28.50^{\prime \prime} \mathrm{N}\end{array}$ & $\begin{array}{l}117^{\circ} 26^{\prime} \\
37.60^{\prime \prime} \mathrm{W}\end{array}$ & 258 & 854 \\
\hline E & $\begin{array}{l}\text { Westfjords, } \\
\text { Iceland }\end{array}$ & 05/08/2007 & ARSF & 700 & periglacial & $\begin{array}{l}66^{\circ} 04^{\prime} \\
13.20^{\prime \prime} \mathrm{N}\end{array}$ & $\begin{array}{l}023^{\circ} 07^{\prime} \\
14.19^{\prime \prime} \mathrm{W}\end{array}$ & 271 & 807 \\
\hline
\end{tabular}

Average elevation is given relative to datum, for A-D this is NAD 1983 and for Site E this is WGS 1984, in both cases the difference between the datum and sea level is approximately 60 m. Abbreviations: NCALM - National Center for Airborne Laser Mapping supported by the USA's National Science Foundation, ARSF - Airborne Research and Survey Facility supported by the UK Natural Environment Research Council. 
Table 2. Summary table for the study sites on Mars

\begin{tabular}{llllll}
\hline Site & HiRISE image pair & Latitide & Longitude & $\begin{array}{l}\text { Average } \\
\text { elevation (m) }\end{array}$ & Relief (m) \\
\hline \multirow{2}{*}{ F } & PSP_001714_1415 & $-38.4^{\circ}$ & $96.8^{\circ}$ & -2648 & 1124 \\
& PSP_001846_1415 & & & & \\
G & PSP_004060_1440 & $-35.7^{\circ}$ & $129.4^{\circ}$ & 300 & \\
& PSP_005550_1440 & & & & \\
& PSP_003418_1335 & $-46.1^{\circ}$ & $18.8^{\circ}$ & 595 & \\
\multirow{2}{*}{$\mathrm{J}$} & PSP_003708_1335 & & & & 961 \\
& PSP_003674_1425 & $-37.4^{\circ}$ & $229.0^{\circ}$ & 1904 &
\end{tabular}

Average elevation is given relative to the Mars datum, as defined from the MOLA dataset. The average elevation has been estimated from the MOLA dataset and relief from the HiRISE DEMs. 